\title{
Government Connections and Financial Constraints: Evidence from a Large Representative Sample of Chinese Firms
}

Cull, Robert, Wei Li, Bo Sun, and Lixin Colin Xu

Please cite paper as:
Cull, Robert, Wei Li, Bo Sun, and Lixin Colin Xu (2015).
Government Connections and Financial Constraints: Evidence
from a Large Representative Sample of Chinese Firms.
International Finance Discussion Papers 1129.

http://dx.doi.org/10.17016/IFDP.2015.1129

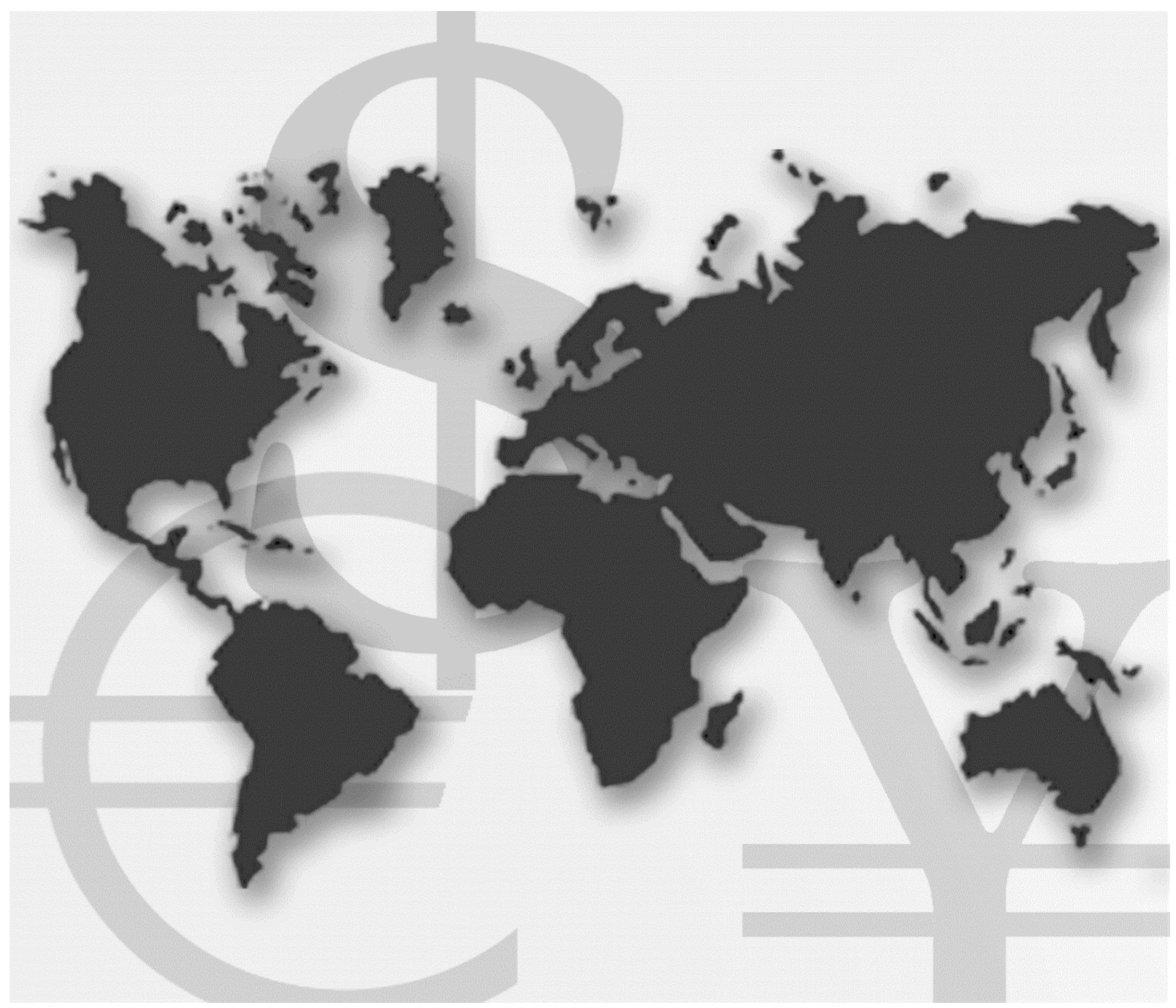

\section{International Finance Discussion Papers}

Board of Governors of the Federal Reserve System

Number 1129

January 2015 
Board of Governors of the Federal Reserve System

International Finance Discussion Papers

Number 1129

January 2015

\title{
Government Connections and Financial Constraints: Evidence from a Large Representative Sample of Chinese Firms
}

\author{
Robert Cull, Wei Li, Bo Sun, and Lixin Colin Xu
}

NOTE: International Finance Discussion Papers are preliminary materials circulated to stimulate discussion and critical comment. References to International Finance Discussion Papers (other than an acknowledgment that the writer has had access to unpublished material) should be cleared with the author or authors. Recent IFDPs are available on the Web at 
www.federalreserve.gov/pubs/ifdp/. This paper can be downloaded without charge from the Social Science Research Network electronic library at www.ssrn.com.

\title{
Government Connections and Financial Constraints: Evidence from a Large Representative Sample of Chinese Firms
}

\author{
Robert Cull, Wei Li, Bo Sun, and Lixin Colin Xu
}

\begin{abstract}
:
We examine the role of firms' government connections, defined by government intervention in CEO appointment and the status of state ownership, in determining the severity of financial constraints faced by Chinese firms. We demonstrate that government connections are associated with substantially less severe financial constraints (i.e., less reliance on internal cash flows to fund investment), and that the sensitivity of investment to internal cash flows is higher for firms that report greater obstacles to obtaining external funds. We also find that those large non-state firms with weak government connections, likely the engine for innovation in the coming years in China, are especially financially constrained, due perhaps to the formidable hold that their state rivals have on financial resources after the 'grabbing-the-big-and-letting-go-the-small' privatization program in China. Our empirical results suggest that government connections play an important role in explaining Chinese firms' financing conditions, and provide further evidence on the nature of the misallocation of credit by China's dominant state-owned banks.
\end{abstract}

Keywords: Financial constraints, investment, political connections, firm size, China, capital allocation, invest cash flow sensitivity

JEL classifications: G18, G21, G28, G38, O16.

One of the authors is a staff economist in the Division of International Finance, Board of Governors of the Federal Reserve System, Washington, D.C. 20551 U.S.A. The views in this paper are solely the responsibility of the authors and should not be interpreted as reflecting the views of the Board of Governors of the Federal Reserve System or of any other person associated with the Federal Reserve System. 
www.federalreserve.gov/pubs/ifdp/. This paper can be downloaded without charge from the Social Science Research Network electronic library at www.ssrn.com.

\title{
Government Connections and Financial Constraints: Evidence from a Large Representative Sample of Chinese Firms
}

\author{
Robert Cull, Wei Li, Bo Sun, and Lixin Colin Xu
}

\begin{abstract}
:
We examine the role of firms' government connections, defined by government intervention in CEO appointment and the status of state ownership, in determining the severity of financial constraints faced by Chinese firms. We demonstrate that government connections are associated with substantially less severe financial constraints (i.e., less reliance on internal cash flows to fund investment), and that the sensitivity of investment to internal cash flows is higher for firms that report greater obstacles to obtaining external funds. We also find that those large non-state firms with weak government connections, likely the engine for innovation in the coming years in China, are especially financially constrained, due perhaps to the formidable hold that their state rivals have on financial resources after the 'grabbing-the-big-and-letting-go-the-small' privatization program in China. Our empirical results suggest that government connections play an important role in explaining Chinese firms' financing conditions, and provide further evidence on the nature of the misallocation of credit by China's dominant state-owned banks.
\end{abstract}

Keywords: Financial constraints, investment, political connections, firm size, China, capital allocation, invest cash flow sensitivity

JEL classifications: G18, G21, G28, G38, O16.

One of the authors is a staff economist in the Division of International Finance, Board of Governors of the Federal Reserve System, Washington, D.C. 20551 U.S.A. The views in this paper are solely the responsibility of the authors and should not be interpreted as reflecting the views of the Board of Governors of the Federal Reserve System or of any other person associated with the Federal Reserve System. 


\section{Introduction}

The presence of financial constraints and its effects on firms’ investment decisions have received intense interest in the corporate finance literature. There is considerable evidence that financing constraints are an impediment to the investment and growth of firms in developed economies (Hubbard 1998, Stein 2003), while less work has been done to further our knowledge about financial constraints in developing countries that have different institutional structures. Firms in developing countries tend to face more severe financial constraints than those in developed countries, and their owners typically name financial constraints as one of their primary obstacles to investment (Dethier et al. 2011). Moreover, the governments of these countries tend to play a larger role in directing financial resources than in developed countries and tend to favor state-owned firms and firms that have stronger ties with the state in the allocation of capital (Ayyagari et al. 2012).

Credit allocation in China has been characterized by government intervention and has been biased towards state-owned enterprises, ${ }^{2}$ and insufficient financial support may impose difficulties in the development of firms that lack government connections. ${ }^{3}$ Employing the World Bank's Enterprise Survey of manufacturing firms in 120 Chinese cities conducted in 2005, we study whether and how firms with differential government connections are financially constrained in China and how that affects their investment patterns. We compare not only state-owned enterprises (SOEs) to non-state firms (both foreign and domestic), but also examine whether CEOs' governmental connections explain financial constraints within the subset of non-state firms.

\footnotetext{
2 See Brandt and Li 2003; Huang, 2003; Bai et al. 2006; Li et al. 2008; Cull, Xu and Zhu 2009; Gordon and Li 2011. ${ }^{3}$ Dollar and Wei (2007) also provide evidence that distorted capital allocation had led to persistent dispersion in returns to capital across sectors and geographic areas. Farrell and Lund (2006) report that by 2006 the private sector had produced more than half of China’s GDP but received only $27 \%$ of total loans.
} 
We consider two forms of government connections: state ownership and the role of government in CEO appointment. A firm is classified as state-owned if it is registered as such based on the level of government shareholding. While state-owned firms have been corporatized and have their own boards of directors, they maintain close ties with their government supervisory entities and owners, and therefore have strong government connections. Firms can also gain and maintain government connections via personnel appointments and personal ties. Specifically, when a firm's CEO is appointed by a government agency, it indicates the firm's institutional ties or its CEO's personal ties to the government. A government-appointed CEO could have achieved this coveted position because the firm under his or her management is state-owned, or formerly state-owned. In our sample, about $8.3 \%$ of the non-state-owned firms have government-appointed CEOs. Government intervention in CEO appointment therefore also serves as an indicator of the extent of the firms' connections to the government for our empirical analysis.

Our empirical results show that the investment rates of sample firms are sensitive to internal cash flows and are also jointly sensitive to access to external finance—bank loans, trade credit and the size of unpledged collateralizable assets (henceforth "UCA"). The finding that the cash flow variable is still significant when we control for various measures of access to external financing suggests that internal financing is crucial for investment. In addition, we find that investment cash flow sensitivity tends to be higher for firms that perceive themselves to be more financially constrained—-that is, when firms report that they face more severe financial constraints in both financial access and financing costs, when firms report having greater difficulty in obtaining loans after the financial crunch in 2003 in China, when firms report less confidence that their property rights will be protected, and when firms are younger. 
The evidence therefore suggests that investment cash flow sensitivity may be a reasonable indicator of financial constraints in the Chinese institutional context, although the validity of this methodology is hotly debated based on data and institutions in developed economies (Kaplan and Zingales 1997, 2000; Fazzari, Hubbard and Petersen 2000; Brown and Petersen 2009). Using U.S. data, Chen and Chen (2012) show that investment cash flow sensitivity is no longer a reliable indicator of financial constraints in the U.S. However, for countries with much lower levels of financial development, such as China, our paper and others (e.g. Moshirian and Vadilyev 2013) offer evidence that this methodology likely remains valid. We therefore take as a working hypothesis that investment cash flow sensitivity is a reasonable indicator of financial constraints for this study.

Our results show how government connections play a key role in explaining firm investment behavior in China. In line with previous studies using different samples and covering different time periods (e.g., Chow and Fung 1998, Héricourt and Poncet 2009, Poncet, Steingress, and Vandenbussche 2010, Guariglia, Liu, and Song 2011), investment in state-owned enterprises in our sample remains insensitive to cash flows, despite substantial institutional reforms undertaken by the central government. ${ }^{4}$ Among non-state and foreign firms, the coefficients for cash flows are positive and significant, indicating that they are financially constrained. However, foreign firms, perhaps because of their greater access to foreign capital, exhibit weaker sensitivities of investment to cash flows than non-state Chinese firms.

\footnotetext{
${ }^{4}$ With specific respect to the banking sector, non-performing assets were removed from the balance sheets of stateowned banks and placed in asset management companies (Hsu and Wan, 2004). State-owned banks have also taken on minority foreign ownership shares, first in smaller banks and later in three of the "Big Four" banks. Evidence indicates that minority foreign ownership was associated with gains in efficiency in the smaller state-owned banks (Berger, Hasan, and Zhou, 2009).
} 
Examining the role of government connections via CEO appointments, we find that investment is more sensitive to cash flows in firms with non-government-appointed CEOs than those with government-appointed CEOs. Additional tests are performed to examine the robustness of these results to various measures of firms' financial conditions. In particular, investment by firms with government-appointed CEOs also displays substantially less sensitivity to access to external finance-bank loans, trade credit, and the level of unpledged collateralizable assets (UCA). Even though or perhaps because firms with non-government-appointed CEOs often have less access to external finance, their investment patterns are more closely tied to the available external finance than firms with government-appointed CEOs. It seems to imply that firms with non-government-appointed CEOs face tighter financial constraints due, at least in part, to their inferior political status in the Chinese credit market.

In addition, we find that investments are less sensitive to indicators of growth opportunities in firms with government-appointed CEOs than in firms with non-government-appointed CEOs. Government-appointed CEOs are subject to different promotion criteria, and are presumed to have incentives to maintain stable employment, and use resources that would otherwise be spent on investment to cover firm arrears or seek favors from government officials who have influence over their future career. Our results are thus consistent with the notion that financial resources received by firms with government-appointed CEOs (including, or course, SOEs) could be diverted to other uses than to fund productive investment projects.

We also find that investments by large firms with weaker connections to the government (i.e., owned by non-state entities and/or run by CEOs not appointed by the government) are especially sensitive to the availability of internal funds, a result that is robust to several plausible sensitivity checks. This could be the result of a crowding out effect in external financing faced by 
large firms without government connections when the government provides privileged access to credit to large firms that are either state-owned or are run by government appointed CEOs. ${ }^{5}$ Another plausible interpretation is that for smaller firms, the need for investment funding is commensurately smaller, and thus it is easier to use informal finance such as funding from friends, relatives or trading partners to meet those needs. For large firms the scale of investment needs is often sufficiently large that informal finance cannot fully meet it, and thus constraints on access to external finance become more binding. Since larger non-state firms are likely to be important engines for growth, this finding is alarming, and speaks to the severe misallocation of credit in China.

The remainder of this paper is organized as follows: Section 2 provides an extensive literature review and background information on government involvement in CEO appointment. Section 3 describes the data and uses our proposed strategy to test for financial constraints in a large sample of firms. Section 4 concludes.

\section{Existing Literature}

Our analysis is related to three distinct literatures about the functioning of financial markets and the financial constraints faced by firms. We discuss each in turn.

\section{Political Connections and Financial Markets}

Political connections are found to be widespread among firms in developing countries and are important resources for those firms. ${ }^{6}$ For instance, politically-connected firms have better

\footnotetext{
${ }^{5}$ Under recent policies, the government privatized small and medium sized state-owned firms, retaining controlling ownership stakes in large SOEs.

${ }^{6}$ See Fisman (2001), Johnson and Mitton (2003), Leuz and Oberholzer-Gee (2006), Faccio (2006), Li et al. (2008), Claessens et al. (2008), Boubakri et al. (2008), Fan et al. (2008), Faccio et al. (2009), Goldman et al. (2009), Cooper et al. (2010), Berkman et al. (2010), Calomiris et al. (2010), Francis et al. (2009), Du and Girma (2010), Wu et al. (2012), Boubakri et al. (2012), Wu et al. (2012), Sun et al. (2011), Chan et al. (2012), and Bliss and Gul (2012).
} 
access to loans ( $\mathrm{Li}$ et al. 2008, Claessens et al. 2008, Fan et al. 2008), have favorable access to equity markets (Francis et al. 2009, Boubakri et al. 2012), have more confidence in the legal system in transitional countries (Li et al. 2008), enjoy more subsidies and tax benefits (Wu et al. 2012 and Lin et al. this issue), and are more likely to be bailed out when facing financial stress (Faccio et al. 2006). ${ }^{7}$ Moreover, there is evidence that politically connected firms tend to be less efficient than unconnected firms (Leuz and Oberholzer-Gee 2006, Fan et al. 2007; Boubakri et al. 2008, Faccio 2010). ${ }^{8}$ For an extensive review, please see Jiang and Kim (this issue).

Relative to politically connected firms in China, politically neutral start-ups experience faster productivity improvement, conditional on survival (Du and Girma 2010), and may strategically appoint outside directors to seek help in dealing with the the government (Chen this issue). The quality of earnings reports from the non-politically connected firms is associated with a lower cost of debt and is, not surprisingly, significantly better than that of similar politically connected companies (Chaney et al. 2011). Lack of political connection also makes firms less immune to government regulations (Berkman et al. 2010). Our findings add to the literature in that we find non-politically connected firms in China face stronger financial constraints, which may stem from a crowding out effect whereby scarce financial resources are channeled to inefficient, but connected firms, resulting in resource misallocation. We provide evidence that unconnected, large, non-state firms are especially financially constrained. We also provide evidence of weaker CEO incentives and lower investment intensity for politically-connected firms.

\section{Measuring Financial Constraints}

\footnotetext{
${ }^{7}$ Jiang et al. (this issue) show that political connections have no effect on the Non-Operational Fund Occupancy actitivies in China, where controlling shareholders directly take funds away from listed firms without matching business transactions.

${ }^{8}$ But political connections also bring returns, as shown by Cooper et al. (2010) and Calomiris et al. (2010).
} 
There has been a long debate on whether the sensitivity of firms' investment to their cash flows should be interpreted as an indicator of financial constraints. The standard identification strategy is based on the pioneering work of Fazzari, Hubbard, and Petersen (henceforth FHP) $(1988,2000)$ who argue that one should be able to gauge the impact of credit frictions on corporate spending by comparing the sensitivity of investment to cash flow across samples of firms. In such studies, a significant correlation between investment and measures of internal funds are attributed to capital market imperfections that give rise to financial constraints. Firms are typically split into sub-samples based on a priori criteria indicating the size of the wedge between the internal and external cost of funds.

An implicit assumption underlying those empirical tests is that investment-cash flow (ICF) sensitivities increase monotonically with the severity of financial constraints. However, Kaplan and Zingales (1997, 2000) provide theoretical reasons why a monotonic relationship between sensitivities and constraints need not hold. They report evidence that firms that paid no dividends (hence classified by FHP (1988) as financially constrained) and that had high investment-cash flow sensitivities did not suffer from financial constraints based on their managements' statements of firm liquidity.

More recent research has documented a decline in the investment-cash sensitivity of U.S. firms and questioned whether the FHP method remains a valid one for identifying financially constrained firms. Chen and Chen (2012) document the decline in sensitivities and the absence of a significant relationship between internal cash flows and investment at the tail end of their period of study (which includes the global financial crisis, a period when financial constraints were likely to be severe). They perform a series of ancillary tests designed to account for changing features of U.S. financial markets, but are unable to uncover a significant relationship between cash flow and 
investment. They conclude that cash flow sensitivity is not a valid measure of financial constraints, or at least it no longer is, for U.S. firms.

Other authors have taken a more nuanced position. For example, Brown and Petersen (2009) document the decline in investment cash flow sensitivity for U.S. firms, but they also show that, among U.S. firms with positive cash flows, investment cash flow sensitivity remained high among young firms at the end of their period of study (1994-2006). ${ }^{9}$ Most investment-cash flow studies have focused on physical investment but Brown and Peterson show that declines in ICF sensitivity have been less pronounced for total investment, and especially for R\&D investment. They also show that the sensitivity of R\&D investment to stock issues by young firms rose from near zero early in their period of study to large and significant values at its end, and that the number of stock issues by small firms increased from zero to high levels throughout their period of study. Similarly, Brown, Fazzari, and Petersen (2009) use dynamic R\&D models to show that young, publicly-traded, high-tech firms displayed much greater sensitivity to both internal cash flows and external equity finance than other firms from 1990 to 2004. In short, there is some empirical evidence that changes in cash flow sensitivities, and the increase in the sensitivity of investment to stock issues, can be explained by the changing composition of investment and improvements in public equity markets in the U.S. ${ }^{10}$

However, we have reasons to take as a working hypothesis that the current Chinese institutional context is suitable for applying the FHP (1988) methodology to study financial

\footnotetext{
${ }^{9}$ Cleary, Povel, and Raith (2007) develop and test a theory showing that investment is not monotonically increasing in cash flows and, in fact, becomes negative for low levels of cash flows (thus justifying Brown and Petersen's focus on positive cash flow firms).

${ }^{10}$ Again, however, Chen and Chen (2012) fail to uncover significant cash flow sensitivities at the end of their period of study (which extends further than that of other authors) in a series of robustness checks designed to account for the changes in U.S. capital markets that are emphasized by Brown and Peterson and other authors.
} 
constraints that Chinese firms face. To begin, the criteria by which we classify firms as being financially constrained a priori is based on the known institutional context in China. There is by now a well-established literature demonstrating that government ownership of the dominant banks in China has resulted in privileged access to bank credit, the primary source of external financing in China, for SOEs. Many of these SOES are chronic loss-makers, resulting in a severe misallocation of credit. In addition, using a smaller sample than we do, Ayyagari, Demirguc-Kunt, and Maksimovic (2010) find that Chinese firms, state-owned or non-state, that report government help as instrumental in obtaining a bank loan do not show subsequent improvements in growth, reinvestment or productivity, unlike other recipients of bank loans. By relying on institutions to identify firms facing financial constraints, our study is similar to Hoshi, Kashyap, and Scharfstein (1991) who classify Japanese firms by whether they belong to a business group (keiretsu) and find that group members have lower investment-cash flow sensitivities than other firms.

In studies using U.S. data, the sample tended to be comprised of large publicly traded firms. The early debate there hinged on whether the lack of dividend payments (the FHP approach) was a more reliable a priori indicator of financial constraints than indicators based on qualitative information in their annual 10-K reports describing all internal and external sources of liquidity (the $\mathrm{KZ}$ approach). The more recent debate focuses on whether investment-cash flow sensitivity continues to be a reliable method for identifying financial constraints, especially in light of capital market developments that reduced the importance of bank loans as a source of funding. Therefore, another reason the FHP methodology may work well in the Chinese context is that, due to China's relatively underdeveloped capital market (Gordon and Li, 2003; World Bank, 2013), formal finance is limited to bank credit for most firms, making it easier to understand the trade-offs they make between internal funds and limited sources of external funds. 
Recent findings also indicate that investment-cash flow sensitivities are more pronounced, and thus a more valid measure of financial constraints, in countries with less developed financial systems. In particular, Moshirian and Vadilyev (2013) show that investment-cash flow sensitivities are more pronounced in emerging markets than in developed countries. Moreover, the decline in ICF sensitivities in emerging markets was much milder than that in developed markets, and becomes even less evident when only firms with positive cash flows are considered. ${ }^{11}$

While bank loans are by far the most important source of external finance for Chinese firms, internal finance exceeds all sources of external finance by a wide margin (Allen, Qian, and Qian, 2005; Guariglia, Liu and Song, 2011). Thus, comparisons of the sensitivity of investment to internal finance would seem to be quite relevant for China, especially since we control for both major sources of funding in our regressions (internal funds and bank loans). ${ }^{12}$ Moreover, to validate the use of FHP methodology in this context, we also perform a number of analyses below to demonstrate that high investment-cash flow sensitivities in our sample are associated with $a$ priori measures of the severity of financial constraints based on firm characteristics and direct responses from firm managers about the financial obstacles that they face (similar to the $\mathrm{KZ}$ approach).

\section{Financial Constraints in China}

\footnotetext{
${ }^{11}$ Those authors also argue that ICF sensitivities remain a good measure of financial constraints in less developed financial systems as they are significantly correlated with other proxies for financial constraints, including leverage, dividends, stock repurchases, R\&D-cash flow sensitivity, inventory investment-cash flow sensitivity, and investment-cash reserve sensitivity.

${ }^{12}$ Also, our data come from 2005, a year when rates of gross fixed capital formation in China were high. Those rates have remained high and even increased in recent years despite the global financial crisis. In contrast, capital investment rates declined dramatically among U.S. firms during the crisis, the period when Chen and Chen (2012) show that investment-cash flow sensitivity disappeared.
} 
There is also an emerging literature on financial constraints in China. Our paper confirms some results from that literature in that we also find that Chinese firms face financial constraints, but state- and foreign-owned firms tend to face less severe ones (Chow and Fung 1998, 2000; Chen 2008; Herícourt and Poncet 2009; Poncet, Steingress, and Vandenbussche 2010; Guariglia, Liu, and Song 2011). Qian and Young (this issue) also provide evidence for inefficiency in bank financing in China. Though some conclusions are similar, our study differs slightly in terms of methodology in that we look at both investment-cash-flow sensitivity and investment sensitivity to access to external finance.

Chan et al. (2011) also examine political connections and financial constraints in China, and find that connected firms are less constrained. However, their measure of political connection is whether the CEO/Chairman was a government official, a military officer or someone with a political ranking at the provincial or ministerial level, while ours is whether the CEO was appointed by the government. Thus their measure represents a very specific connection related to provincial level political ranking, while our measure represents government connection at all levels for all types of firms.

Another distinction between our study and other studies of financial constraints in China is the representativeness of our sample and the time period that we cover (see Table A.1. for a brief summary of other related studies). Most of the existing studies tend to focus on relatively large firms, making it difficult to assess financial constraints of small firms (relative to large firms), which we intend to do using our data. For example, Chan et al. (2012) and Chen (2008) use only listed firms, which are large firms that are likely to face the least severe financial constraints (Wang, Xu and Zhu 2004). Poncet, Steingress, and Vandenbussche (2010) use a sample of 22,300 
observations from 15,000 large firms from 1998 to $2005 .{ }^{13}$ While the sample used by Guariglia, Liu, and Song (2011) is larger than ours and includes all SOEs, it excludes small non-state firms (i.e., it only includes firms with annual sales of more than 5 million yuan). Other studies contain firms of all sizes but are more limited in geographical scope. Chow and Fung $(1998,2000)$ use a panel of manufacturing firms, $80 \%$ of which have more than 100 employees, operating only in Shanghai over the period 1989-1992, while Héricourt and Poncet (2009) use data from 1300 firms, primarily of small and medium size, in 15 provinces from 2000 to 2002. In contrast, our sample covers 12,400 firms of all sizes in all provinces except Tibet. Moreover, the vast majority of studies mentioned here only compare the degree of financial constraints across ownership or sizes, and one of our main focuses is to compare the degree of financial constraints across firms with and without political connections. ${ }^{14}$ We also cover a relatively late period, that is, 2005.

In summary, we differ from existing studies of financial constraints in China in that (a) we provide direct tests of how financial constraints vary with CEOs' connections to the state, (b) we show that government connections matter for financial constraints and investment within the subsample of non-state firms, (c) we provide robust evidence that large non-state firms without government connection tend to be most severely constrained among firms of all sizes, and (d) we use a more recent, representative sample of Chinese firms. We also offer evidence consistent with the working hypothesis that investment-cash flow sensitivity is a reasonable indicator for identifying financial constraints among Chinese firms operating under the Chinese institutions.

\footnotetext{
${ }^{13}$ Those firms had at least 150 employees, US\$10 million in annual sales turnover, and/or US\$20 million in total assets.

${ }^{14}$ An exception is Chan et al. (2012), which also looks at financial constraints by political connection, but their sample consists of listed firms, which are likely far less financially constrained than non-listed firms.
} 


\section{Empirical tests}

We rely on the World Bank 120 city survey of Chinese manufacturing firms conducted in 2005. It covers 12,400 firms located in 120 cities of all Chinese provinces except Tibet. In each province, the provincial capital, which is often the most populous city, is automatically covered, and additional cities are selected based on the economic size of a province. One hundred firms were sampled in each city, except for the four mega cities (Shanghai, Tianjin, Beijing, and Chongqing) where 200 firms were selected. Within the top 10 industries in terms of value added in each city, firms were randomly selected, including large, medium-sized, and small firms. Our sample is thus quite representative of China as a whole, and of firms of various sizes. This is a key advantage when compared to other studies of financial constraints in China since external validity about the existence of financial constraints depends on the representativeness of the sample. Given the geographic imbalance in economic development and the government preferences towards large firms in China, results based on data from selected provinces and firms of certain size can be misleading.

The variables used in our analysis come from a questionnaire consisting of two parts: the first asks for qualitative information about the firm in the survey year and is filled out by firms' senior managers; the second covers financial and quantitative information, much of which goes back three years, about the firms' production and operation, and is directly obtained from the firms' accounting books through the assistance of the firms' chief accountants.

\section{Empirical Specifications and Construction of Variables}

We start with a parsimonious model of investment: 
$\frac{I_{i t}}{K_{i t-1}}=X_{i t}^{\prime} \theta+F_{i t} \beta+\frac{C F_{i t}}{K_{i t-1}} \delta+\frac{S_{i t}}{K_{i t-1}} \alpha_{s}+G_{i t} \alpha_{G}+\varepsilon_{i t}$

where $I$ represents investment, $K$ represents capital stock (as measured by the net value of fixed assets), ${ }^{15}$ and $X$ includes a vector of covariates capturing basic firm and regional characteristics (including area dummies, log of real city GDP per capita, log of city population, log of firm age, non-state ownership and foreign ownership). $F$ is a vector measuring access to external finance, including a dummy variable for having access to bank finance, another for access to trade credit, and the ratio of unpledged collateralizable assets (UCA) to lagged capital stock. Access to bank finance is measured by the dummy variable indicating whether a firm had any outstanding bank loans at the time of the interview. Access to trade credit is measured by the share of inputs purchased via trade credit. UCA is measured as the value of fixed assets minus total loans and then divided by the lagged value of fixed assets. ${ }^{16}$ UCA is therefore a measure of access rather than usage of external credit because it summarizes assets that could be pledged in order to obtain future loans.

In the regression equation, $C F$ denotes cash flows, measured as the summation of net income, interest payments, financing charges, and tax payable. ${ }^{17} S$ denotes sales. For growth opportunities, $G$, we use two variables: lagged sales growth of the firm, and industry level Tobin’s Q. ${ }^{18}$ Since many of the firms in our sample are not publicly traded, we do not have sufficient

\footnotetext{
${ }^{15}$ We do not have a long enough panel to construct a more rigorous measure of capital stock such as through using the perpetual inventory method.

${ }^{16}$ We do not have data on total loans, which are instead proxied by interest payments divided by the average interest rate for loans with maturities between one and three years.

${ }^{17}$ We have also tried the same measure but excluding tax payable. The two proxies have a correlation coefficient of 0.999 , so it is no surprise that the results are similar using either measure.

18 Tobin's Q ratio is the market value of a firm's total assets divided the book value of those assets.
} 
information to compute firm-level Tobin's Q ratios. We therefore rely on data from all listed firms in China to compute an industry-level average Tobin's Q using the value-weighted formula. ${ }^{19}$

To the extent that the FHP methodology is valid under the Chinese institutional context, an increase in cash flows, which is assumed to convey no additional information about firms' investment opportunities, would be associated with a rise in investment spending for financially constrained firms. We therefore expect a positive coefficient for the cash flow variable in this regression model if firms' investment is influenced by their availability of internal funds. In addition to the sensitivity of investment to cash flows, we also include access to bank loans, trade credit and UCA as indicators of access to external finance. We view this as an informative additional check on the relative severity of financial constraints, to the extent that investment remains relatively more sensitive to internal cash flows for firms with weaker connections to the government when these variables are included in the regression.

Since some $X$, all $F$, and lagged sales growth rates are available for only one year, we use the cross sectional estimation method in our base specification. For $C F$, Tobin's $\mathrm{Q}$, and sales intensity, we have two years of data, and so we also present fixed effects specifications in models with fewer variables than in the base specification. In those models, we are relying on within-firm differences to identify the effects of cash flows and Tobin's Q on investment. Many of our variables have notable outliers, such as investment intensity (and its two variants), sales intensity, $C F$, and sales growth. We therefore winsorize the observations using a 1 percent tail wherever

\footnotetext{
${ }^{19}$ We obtain similar results when using the industry-year median from the same data set of listed firms and after experimenting with various ways to value non-tradable shares.
} 
appropriate to reduce the influence of those outliers. ${ }^{20}$ For reference, we provide a list of variable definitions in Table A.5 in the Appendix.

\section{Summary Statistics and Patterns}

Table 1 reports summary statistics for the full sample. We define firms' ownership type based on the response to the corresponding question in the questionnaire. If the answer to the ownership type question is "state", the firm is categorized as state-owned; if the answer is "foreign" or "Hong Kong, Macao and Taiwan", the firm is categorized as foreign; if the answer is corporation, collective, or private, the firm is categorized as non-state in our sample. The majority (78 percent) of our sample is non-state firms, while foreign-owned firms account for 12 percent.

The average age of firms is 13.7 years. On average, 60 percent of firms had bank loans, while the share of inputs purchased through supplier credit was about 9 percent. The average ratio of sales to lagged capital stock is 6.6, and the average once-lagged sales growth rate is 53 percent. The high level of sales growth is partly accounted for by observations in the tail of the distribution. The median lagged sales growth is much lower at 22 percent.

In Table 2, we report summary statistics separately for firms with government-appointed CEOs and with non-government appointed CEOs. Our classification of firms by government involvement in CEO appointment is based on the manager's response to the question: "Is the CEO appointed by the government?” In the data, about $8.3 \%$ (before we winsorized the data) of CEOs of non-state domestic firms are appointed by the government, and 54\% of CEOs of state-owned

\footnotetext{
${ }^{20}$ This is important since otherwise a handful of observations could drive our results. For instance, while the trimmed $\mathrm{CF} / \mathrm{K}_{\mathrm{t}-1}$ has a mean of 0.34 (with a standard deviation of 0.88 ), the 99th percentile for the two years of data is more than 15.
} 
enterprises are appointed by government. Our data thus confirm that the Chinese government continues to exert control over the appointment of CEOs in many state-owned enterprises even after corporatization reforms. But it is surprising that for a small fraction of non-state firms, the Chinese government still exerts influence over the selection, appointment, and dismissal of top executives. One institutional explanation is that some privatized SOEs have retained CEOs appointed by the government before privatization. Another explanation is that the government may still hold substantial ownership stakes in some privatized SOEs and can influence personnel decisions via its representatives in the boardrooms. And some non-state firms may find it advantageous to institutionalize their connections to the state by inviting government involvement in CEO appointments. ${ }^{21}$ In addition, the government has ultimate authority in CEO appointment in non-state firms that are considered systemically or strategically important, such as large financial institutions. ${ }^{22}$

Table 2 shows that relative to those with non-government-appointed CEOs, firms with government-appointed CEOs have lower average investment intensities (0.18 versus 0.36 ), are much older (26 versus 12 years old), and are much more likely to be state-owned (45 percent versus 5 percent). They also have lower sales over lagged capital stock (3.56 versus 7.03), lower cash flow over lagged capital stock ( 0.36 versus 0.64$)$, and lower sales growth (33 percent versus 56 percent) than firms with non-government-appointed CEOs. They are thus less profitable and growing more slowly. However, in terms of loan access or the usage of trade credit, these two types of firms are similar. Qualitatively similar patterns also emerge within the sub-sample of

\footnotetext{
${ }^{21}$ CEOs appointed by the government often have comparative advantage in dealing with various functions of the government, since they presumably have the relevant political experience and have cultivated close personal relationships with officials.

${ }^{22}$ For example, many private banks, such as China Merchants Bank and Shanghai Pudong Development Bank, have their CEOs directly appointed by the government.
} 
non-state domestic firms (Table 2). The descriptive patterns are consistent with our hypothesis that firms with government-appointed CEOs tend to have lower investment intensities.

Table 3 showcases differences in firm characteristics by size. We classify firms into three size categories: small (i.e., those in the bottom quartile in capital stock), medium (those in the middle two quartiles), and large (those in the top quartile). Small firms have significantly higher investment intensities ( 0.53 compared with 0.30 for medium and 0.24 for large firms), but have much worse access to finance on almost all indicators. Yet they also have the highest sales to capital ratios (14.7 compared with 4.6 for medium and 2.8 for large firms), the highest cash flow to capital ratios (1.11 compared with 0.51 and 0.34 ), and the highest sales growth rates (64 percent compared with 51 and 48 percent). The same patterns are evident within the subset of non-state domestic firms. The data therefore suggest that small firms, which are high growth firms, are likely to face relatively severe financial constraints.

\section{Investment Equation Based on the Pooled Sample}

Since investment intensity is left censored at zero, a useful starting point would be the Tobit specification. However, since we are primarily interested in marginal effects of the cash flow and finance variables, Angrist (2001) suggests that it is equally appropriate to rely on a linear specification for ease in interpreting results. We therefore mainly focus on linear regressions in our empirical tests. The qualitative results of the Tobit and linear regressions are very similar.

Columns (1) and (2) in Table 4 show Tobit and OLS results without controlling for growth opportunities or proxies for access to external finance. Columns (3) and (4) add the external financing variables. Column (5) then adds the industry dummies to control for industry-specific growth opportunities, while column (6) provides an instrumental variables regression that treats 
the cash flow variable as being endogenous. In Column (7), we add lagged sales growth and industry average Tobin's Q (but without the industry dummies), and column (8) reports the fixedeffects results. Since the qualitative results for our key variables are very similar for the Tobit, IV, and OLS results, we rely on OLS and FE from this section forward.

Controlling for growth opportunities (in columns 7 and 8) does not alter our key results. This is reassuring since one argument against the interpretation of coefficients of cash flows as indicators of financing constraints is that they are also a proxy for investment opportunities. The effects of growth opportunities are of the expected signs: positive and significant, in both OLS and FE results.

Our proxies for access to external finance are strongly correlated with investment in our sample. Increasing access to bank loans by one standard deviation $(\sigma)$ would increase investment intensity by roughly 0.075 , which translates into 0.085 of the standard deviation for the investment intensity variable. Usage of trade credit is also significantly associated with investment, consistent with the literature that finds that trade credit has played a positive role in China's development given its poor financial infrastructure (Allen, Qian, Qian 2005; Cull, Xu and Zhu 2009). ${ }^{23}$ Increasing trade credit by one $\sigma(0.195)$ would increase investment intensity by 0.015 . The effects of formal finance through the banking system are therefore five times as large as those of informal trade financing arrangements. The availability of collateralizable assets (UCA) is also positively associated with investment. Increasing UCA by one $\sigma$ (1.64) would increase investment intensity by 0.05 .

\footnotetext{
23 The importance of trade credit for explaining firm performance in general and African firm performance in particular is also observed in cross country firm samples (Harrison, Lin and Xu 2011).
} 
Most importantly for our analysis, normalized cash flow is significantly and robustly associated with investment in our sample. Increasing it by one $\sigma(1.43)$ would increase investment intensity by 0.15 . For other control variables, notable findings are that non-state firms tend to have higher investment intensities, and that younger firms tend to invest more. Those findings are consistent with the notion that young non-state firms have higher growth opportunities, as was suggested by the summary statistics.

Some of the recent papers on financial constraints in China have employed estimation methods that deal with the potential endogeneity of the cash flow variable. We follow Poncet, Steingress, and Vandenbussche (2010) in using lagged values of cash flows as instruments for current cash flows. Because we have information on cash flows for only the year of the survey and two years prior, and because the cash flow variable is deflated by lagged capital stock by construction, we are able to use only a single lag of the cash flow variable in the IV regression in column (6). In the first stage, the instrument is highly statistically significant, with a t-statistic of 14.5, and thus satisfies the relevancy criterion for a good instrument. It is questionable whether the lagged cash flow satisfies the validity criterion, that is, is not correlated with the error directly, and thus the IV results should be viewed only as a sensitivity check. ${ }^{24}$ As noted, because the IV results are very similar to the OLS and FE regressions with regard to the effects of cash flows and external sources of finance on investment, we do not present IV results in the robustness checks that follow. ${ }^{25}$

To summarize, the results based on the pooled sample suggest that on average Chinese firms face financial constraints since their investment rates are sensitive to access to bank loans,

\footnotetext{
${ }^{24}$ When the error term is significantly auto-correlated, for instance, the IV would be invalid.

25 The IV results are, however, available from the authors.
} 
trade credit, and to the availability of collateralizable assets, and are sensitive to cash flows under the working hypothesis that the FHP method remains valid in the Chinese institutional context.

\section{Assessing the Validity of ICF Sensitivity as a Measure of Financial Constraints}

As acknowledged by Fazzari, Hubbard, and Petersen (1988) and Hoshi, Kashyap and Scharfstein (1991), the standard criticism of using the investment-cash-flow sensitivity analysis to examine the effects of liquidity constraints is that liquidity variables also reflect unobserved investment opportunities. Since it is generally difficult to find convincing instrumental variables for liquidity variables in the investment equation, they propose classifying firms into various subsets based on a priori beliefs about the relative severity of information and liquidity problems faced by firms, and then checking whether the cash flow sensitivity is indeed larger for firms classified as facing greater information/liquidity problems.

Here we use information from our survey to construct proxies for the relative severity of information and liquidity problems faced by the firms in our sample. The first measures are based on direct responses by firm managers about the severity of financial constraints that they face. The approach is similar in spirit to that in Kaplan and Zingales (1997), which used information in the 10-K reports of U.S. firms to construct measures of financial constraints. Our first measure is based on the response to: "please rate the level of obstacle that the firm faces in financing means (such as collateral): no obstacle, minor obstacle, medium obstacle, severe obstacle, complete obstacle.” If the answer is a "severe" or "complete" obstacle, a firm is classified as financially constrained. The second comes from the response to: "please rate the level of obstacle that the firm faces in financing costs (such as interest rates): no obstacle, minor obstacle, medium obstacle, severe obstacle, complete obstacle." Again, if the answer is a "severe" or "complete" obstacle, a firm is 
classified as financially constrained. A third measure is derived from the response to: "since the macro adjustment program beginning in the end of 2003, how difficult has it been for your firm in obtaining loans from formal financial institutions relative to before? Please choose from: cannot obtain loans; much more difficult; slightly more difficult; no change; easier.” A firm is classified as financially constrained if its manager indicated more difficulty in obtaining loans since the macro adjustment program.

As proxies for the information problems faced by firms (and the associated problems in obtaining external finance), we use firm age and managers' perceptions about the security of property rights. We expect young firms (those with ages below the sample median), and those that have less confidence in the security of their property rights than the median sample response, to be facing more severe credit constraints. Although differences between constrained and unconstrained firms are larger for some indicators than others, the regressions in Table 5 indicate that ICF sensitivity is greater for a priori constrained firms across all five of our measures. ICF sensitivity is more pronounced for young firms, those that report financing is a significant obstacle, and those that perceive property rights to be less secure. We view these findings as further corroboration for the working hypothesis: The ICF sensitivity methodology is valid in the Chinese context.

As described above, cash flows tend not to be a significant predictor of investment for firms with negative cash flows (Chen and Chen, 2012; Moshirian and Vadilyev, 2013). In Table 6, we therefore check whether ICF sensitivity is larger when those firms are dropped from the sample. We find that the cash flow coefficient increases when firms with negative cash flow are dropped, though the increase is a modest one (Columns 1 and 2). Also described above, the decline in ICF sensitivity for the U.S. has been ascribed to R\&D-cash-flow sensitivity being higher than that for 
physical investment, as R\&D has increased as a share of total investment (Brown and Peterson, 2009). We therefore re-run our base specification using total investment (physical plus R\&D) as the dependent variable (Table 6). We confirm that ICF sensitivity is greater using an investment measure that includes $R \& D$, though the gain is a small one. The coefficient on the cash flow variable increases from .105 to .113. Still, the results of both the additional tests in Table 6 point in the predicted directions, and one might expect the gains in ICF sensitivity to be smaller when making these adjustments to a sample of Chinese firms.

\section{Robustness Checks for the Base Specification}

It is possible that our specifications in Tables 4-6 have not included some plausible explanatory variables, and if these omitted variables are correlated with our key variables, our inference so far would have been made based on inconsistent estimates. Table 7 therefore is designed to shed light on the sensitivity of the estimates for our key coefficients to the inclusion of potentially relevant omitted variables. For comparison, we report the results from our base specification in the first column.

First, the level of infrastructure in the region where a firm operates may determine its investment intensity, access to finance and cash flows. ${ }^{26}$ For instance, good infrastructure boosts the extent of the market and can lower input costs, which therefore encourages investment. Anticipating higher returns associated with better infrastructure, banks and suppliers could be more willing to supply credit to firms operating in regions with better infrastructure. In column (2) of Table 7, we therefore control for three proxies of the quality of local infrastructure that come directly from our data: the firm's loss of sales due to power outages, due to transport problems

\footnotetext{
${ }^{26}$ See Xu (2011) for a survey of some recent evidence on how infrastructure affects firm performance in developing countries.
} 
(such as breakage and theft), and graded road density for the city (i.e., kilometers of graded roads per thousand city residents). Table 7 shows that the estimates of our key parameters remain largely unchanged after the inclusion of local infrastructure variables. For instance, the coefficient for cash flow over capital was 0.107 in the base specification and is now 0.106 , both significant at the 1 percent level. Our financial constraints results therefore are unlikely to be attributable to regional variations in the underlying quality of infrastructure.

Second, due to varying degrees of state ownership or past state involvement within privatized firms, they likely differ in their autonomy over investment. Investment autonomy has the potential to explain both financing and cash flow variables and thus investment intensity. In column (3) of Table 7, we therefore add an index of autonomy in investment. This variable, which is also available from the survey, measures the degree of managerial control over investment, which varies from 0 to 100 , with 0 meaning no control, and 100 meaning full control. Again, all key parameters are very similar to our base results. One minor exception is trade credit, whose coefficient changes from 0.079 to 0.089 , but it remains statistically significant at nearly the same level. Thus our results on financial constraints are unlikely to be attributable to inter-firm differences in investment autonomy.

Third, managerial human capital has become an increasingly popular explanation for firm behavior and performance (see, for instance, Bruhn, Karlan and Schoar 2010). Since it is certainly plausible that CEOs with stronger incentives and qualifications tend to have higher investment rates and better access to finance, omitting variables that summarize managerial human capital could overstate the contribution of financing variables. In column (4) of Table 7, we control for many CEO characteristics, including years of schooling, whether the CEO was appointed by the government, whether the firm has a board of directors, the ratio of CEO pay to that of the typical 
worker at the firm, and whether there are explicit incentive provisions in the CEO's contract. Including CEO characteristics does reduce the magnitude of some financing variables, but only slightly: for example, the coefficient for access to loans drops from 0.155 to 0.140 , and that of trade credit from 0.079 to 0.073 . The coefficients related to external finance and cash flows are generally very similar, however. Thus our conclusions about financial constraints are not overturned by the inclusion of CEO characteristics in our regressions.

It is also worth pointing out that CEO schooling and the existence of a board of directors are significantly positively related with the level of investment, while government intervention in CEO appointment tends to decrease investment. The negative association between investment and government intervention in CEO appointment supports the notion that, although government connections mitigate financing constraints, incentive problems may reduce investment intensities in firms with government-appointed CEOs.

Fourth, institutions have been argued to be important determinants of both national and firm performance (North 1990; Knack and Keefer 1995; La Porta et al. 1997, 1998, 2000; Acemoglu, Johnson, and Robinson 2001, Harrison, Lin and Xu forthcoming). The impact of institutions is so pervasive that we can easily imagine their quality determining both access to finance (La Porta and others 1997, 1998, 2000) and investment (Knack and Keefer 1995). To control for this possibility, we include the CEO's perception of whether local government officials facilitate firm development (government help) and the likelihood that a firm's property rights will be protected by the legal system in commercial disputes. In addition, we include "entertainment and travel cost expenses” (ETC) in our regression to tease out the potential influence of corruption. ETC covers entertainment (including eating, drinking, gifts, karaoke, and sports club membership) and travel expenditures. Besides legitimate business travel and other expenses, Chinese managers 
commonly use the ETC accounting category to reimburse expenditures used to bribe government officials, to entertain clients and suppliers, or to accommodate managerial excess. ETC is a standard expenditure item publicly reported in accounting books of Chinese firms, and we use it as a measure of corruption in Chinese firms, as justified by Cai, Fang and Xu (2011). The results are reported in column (5) of Table 7. Again, our key coefficients remain stable after controlling for proxies for institutional frictions, though admittedly none of those proxies are themselves significant.

The strongest test of omitted variable bias is to include all of these groups of variables in the same regression, as we do in the last column of Table 7. Our key results regarding cash flows and external financing remain robust. The coefficients are very similar to our base specification reported in column (1) where we do not control for any of these additional variables. Our regression results on the effects of liquidity constraints are therefore unlikely to be an artifact of the omission of potentially pertinent variables.

Another potentially useful robustness test is to examine whether our results regarding financial constraints hold if we estimate the investment equation separately for each industry (see Appendix, Table A.4). Allowing industry-specific investment equations has the advantage of holding technology constant and therefore reducing the scope for omitted variable bias. Most of the results on cash flow and access to external finance continue to hold. For instance, in seven of the eight industries, ${ }^{27}$ the coefficient for cash flow over lagged capital is positive and significant.

\footnotetext{
${ }^{27}$ We study the following eight industries. Industry 1 includes agricultural processing, wood processing, furniture, paper, food, drink, tobacco, educational and sports goods, craft, and printing. Industry 2 includes textiles, cloth shoes and hats, and leather. Industry 3 includes petroleum, chemical fiber, chemical materials, rubber, and plastic. Industry 4 represents general equipment. Industry 5 includes communication equipment and electronics. Industry 6 includes specialized equipment, instruments, medical equipment, and transportation equipment. Industry 7 includes metal, non-ferrous metals, and ferrous metals. Industry 8 includes non-metal manufacturing.
} 
In all eight industries, the coefficient for access to bank loans is positive and significant. The coefficient for UCA is also generally significant. Trade credit is an exception, in that it becomes generally insignificant. This suggests that the positive correlation between trade credit and investment intensity in our base results largely stems from variation across industries. Overall, the industry-specific investment equation estimations are reassuringly supportive of the base results in Table 4.

\section{Using liquidity classifications based on political connections to check the effects of financial constraints}

As described above, we classify firms based on their degree of state ownership (institutionalized connections) and whether the CEO was appointed by the government (CEO personal connections). We hypothesize that firms with close connections to the government have easier access to external financing, weaker incentives to be profitable, and lower investment-cashflow sensitivities.

\section{Firm ownership}

We estimate Equation (1) for three ownership groups: state-owned enterprises (SOEs hereafter), non-state domestic firms, and foreign firms. Ex ante we expect non-state domestic firms to face more severe financial constraints due to their lack of institutionalized government connections, and the discrimination of the state-owned banking system against non-state firms in China (Brandt and Li 2003; Cull, Xu and Zhu 2009). The results are reported in Table 8.

Consistent with the literature, we find that SOEs' investment is not sensitive to cash flows. The estimate of the coefficient for the cash flow over lagged capital variable is insignificant for the OLS specification, and even negative for the fixed-effects specification. This pattern is 
consistent with our conjecture that SOEs benefit from favorable treatment by banks and have greater access to finance. For non-state domestic and foreign firms, the estimates of the coefficient for the cash flows variable are positive and significant for OLS, though the coefficient for nonstate firms is larger. In the fixed-effect specification, the cash flow variable has a significant effect on investment only for non-state firms. Both the OLS and the fixed effect specifications therefore indicate that non-state domestic firms are more financially constrained than foreign firms. This is consistent with our priors that foreign firms, because of greater access to foreign capital, should exhibit smaller sensitivities of investment to cash flows than non-state Chinese firms.

It is worthwhile to point out that investment in foreign firms is more closely correlated with their access to loans. This could be due to a peculiar institutional friction caused by local authorities' competition for foreign direct investment (FDI). In an effort to attract foreign firms to a location, local governments in China often offer loans as matching funds for FDI entry (Huang 2003), and access to those loans may translate into more investment by foreign firms than domestic ones.

\section{CEOs’ government connections}

We examine whether government connections influence financial constraints firms face by estimating the investment equation separately for firms with government-appointed CEOs and those with non-government-appointed CEOs (Table 9). The estimate of the cash flow coefficient for firms with non-government-appointed CEOs is more than double that for firms with government-appointed CEOs in the OLS specification, and about 50 percent larger in the fixed effect specification. Moreover, the estimated coefficient is only significant for firms with nongovernment-appointed CEOs in the OLS specifications. Investment in firms with non- 
government-appointed CEOs is also much more sensitive to access to loans, access to trade credit, and UCA. Though firms with government appointed CEOs receive as much external finance as those with non-government-appointed CEOs (Table 2), that finance does not appear to spur investment. $^{28}$

Government-appointed CEOs are subject to different reward systems and may have the tendency to use resources that would otherwise be spent on investment to seek favors from government officials who have influence over their future career. This notion is broadly supported by the data. There are two variables in the survey that measure CEO incentives. The first is a dummy equal to one if CEO pay is linked to firm performance. A second variable is the manager's response to: "What is the percentage increase (decrease) in CEO annual pay if the firm's performance surpassed (fell below) its pre-specified target last year?” Table 10 shows that both measures are higher for non-government-appointed CEOs than government-appointed ones. As a result, and as indicated in Table 2, firms with government-appointed CEOs have lower investment intensities than firms with non-government-appointed CEOs. Furthermore, the OLS results in Table 9 show that the investment of firms with government-appointed CEOs is less sensitive to indicators of growth opportunities than those of firms with non-government-appointed CEOs.

These pieces of evidence support the liquidity constraint hypothesis: firms facing better growth opportunities and stronger incentives, that is, firms with non-government-appointed CEOs, are more financially constrained, and they readily translate greater access to internal and external finance into investment.

\section{Additional Checks: Firm Size}

${ }^{28}$ Cull, Xu and Zhu (2011) suggest that the leakage of loans to SOEs to trade credit is a possibility. 
So far we have shown evidence that financial constraints are more severe for firms in the non-state sector, especially those that lack strong ties to the government. Within that set of firms, we next investigate whether constraints are more severe for some than others. We focus on firm size. In the literature small firms are presumed to have less access to finance because they lack collateral and credit histories, making it difficult for banks to assess their creditworthiness (Berger and Udell, 2006; Beck, Demirguc-Kunt, and Martinez Peria, 2011). In China, weaker connections with government could put small firms in an even more disadvantageous situation when obtaining external funds.

We classify firms into 3 groups based on their capital stock in 2003, one year prior to the survey. The bottom, middle two, and top quartiles are defined as small, medium-sized, and large firms respectively. Surprisingly, it is the large non-state domestic firms that show the highest sensitivity of investment to cash flows (Table 11). The cash flow coefficient for large non-state firms is 2.5 times that for small firms. While somewhat surprising in an international context, since in most countries small firms tend to be most financially constrained, the results are plausible under the Chinese institutional context. ${ }^{29}$ Non-state firms that grow to be large despite poor access to finance and other obstacles tend to be especially well-run. For one, large non-state firms are likely to face strong competition, since the ownership restructuring program in the decade around 2000 was guided by the principle of "grabbing the big and letting go the small", which essentially privatized almost all small- and medium-sized enterprises, and non-profitable large enterprises, and kept large, profitable enterprises as state-owned (Zhu 1999; Lin and Zhu 2001; Xu, Zhu and Lin 2005). Non-state firms that have grown large likely face the toughest market tests. They not

\footnotetext{
${ }^{29}$ On the relative severity of financial constraints for small firms in other countries see, for example, Beck, Demirgüç-Kunt, and Maksimovic (2005).
} 
only have to fend against other non-state competitors, they must compete against large SOEs, often not on a level playing field. Indeed, the top large SOEs tend to be ministerial-level appointments within the Communist Party apparatus, and their CEOs have a unique red phone that can directly dial up top government officials, unlike other SOE CEOs (McGregor 2010). Large SOEs also have better access to bank loans, as the state-owned banks show strong bias in favor of SOEs in their lending (Boyreau-Debray, 2003; Cull and Xu, 2003; Gordon and Li, 2003; Allen, Qian, and Qian, 2005; Boyreau-Debray and Wei, 2005; Cull, Xu, and Zhu, 2009; and Gordon and Li, 2011). Adding to the difficulties of large non-state firms in access to external finance is the fact that the equity market in China also strongly favors SOEs (Gordon and Li, 2003; Wang, Xu and Zhu 2004; Francis et al. 2009). Large non-state firms thus have to be especially well run to survive in such fiercely competitive markets. It is therefore not surprising that they have higher return from investing their internal funds than other firms.

In addition, for smaller firms, the need for investment funding is commensurately smaller, and thus it is easier to use informal finance such as funding from friends, relatives or trading partners to meet those needs. For large firms, the scale of investment needs is so large that informal finance cannot fully meet it, and thus constraints on access to external finance are more binding.

Combining their battle-tested survival capabilities, their investment needs that are too large to rely on informal finance, and their disadvantaged access to finance due to institutional bias, it is plausible that those large non-state firms face especially harder financial constraints than small and mid-sized non-state firms. Our finding of larger investment-cash-flow sensitivities for large non-state firms versus SMEs, while surprising in other countries, is plausible in the Chinese institutional context. Since larger non-state firms are likely to be important engines for growth, 
this finding, in light of our analysis, speaks to the presence of severe misallocation of capital in China.

Regarding external finance, the patterns for the three groups are broadly consistent with the stylized facts drawn from Table 3. Smaller firms have worse access to finance. For small, medium-sized and large firms, the shares of firms with access to bank loans are 37, 61 and 79, respectively; the average shares of inputs purchased with trade credit are 7.6, 8.2, and 10.6 percent, respectively; and the share of unpledged collateralizable assets is 2, 10 and 21 percent, respectively. In the regressions, the coefficients for proxies for access to external finance are more pronounced for small firms than for medium-sized and large firms. For example, for small, medium-sized and large firms, the coefficients for access to bank loans are $0.31,0.17$, and 0.05 (not statistically significant), respectively. This pattern could indicate that, although relatively few small firms receive external finance, those that do are especially strong performers and especially likely to use those funds to invest in the growth of their businesses.

Since the finding of much stronger financial constraints for large non-state unconnected firms may run counter to many readers’ priors, we conduct several additional checks. First, we clarify whether the result of greater financial constraints for large firms holds only for nongovernment-appointed CEOs. In table 12, we re-run the results separately for governmentappointed CEOs and non-government-appointed CEOs. Since in this paper we argue that government connections provide a key reason for (less severe) financial constraints, our prior is that the degree of financial constraint should not matter much for firms with government-appointed CEOs, regardless of their size - they all have good connections and therefore good access to finance-and that the degree of financial constraint should differ by size for firms without government connections (i.e., that have non-government-appointed CEOs). The results are 
consistent with our priors. The coefficient for the cash flow variable tends to be small and insignificant for firms with government-appointed CEOs. However, for firms with nongovernment-appointed CEOs, the cash flow coefficient increases monotonically from 0.10 to 0.16 to 0.28 for small, medium and large firms. It is thus large non-state firms without government connections that suffer most in terms of financial constraints. Large non-state firms with government connections do not suffer much with respect to financial constraints.

Second, we check whether the stronger investment-cash-flow sensitivity for large non-state firms without government connection is a mere artifact of the correlation between cash flow and growth opportunities, the classical concern in this literature. In other words, it is possible that the larger magnitude for the cash flow coefficient for these firms merely reflects greater growth opportunities and the stronger correlation between cash flow and growth opportunities. Since growth opportunities are partially unobserved and in the error term, in principle this stronger correlation is impossible to test. However, Altonji et al. (2005) suggest a useful way to detect the seriousness of the bias of the key (potentially endogenous) variable by checking the extent to which that variable is correlated with the observable components of the unobservable growth opportunities. To the extent that observable components are not strongly correlated with the key endogenous variable, or do not alter the coefficient of the key variable much, we have greater confidence in the estimate.

Here, we have two observable components of growth opportunities, lagged sales growth of the firm, and the average industry Tobin's Q. If the larger investment-cash-flow sensitivity for large non-state firms without government connection merely reflects omitted growth opportunities, we would expect a stronger correlation between cash flows and those two variables. In Table 13, we regress cash flow on the two proxies of growth opportunities, along with their 
interaction with the medium and large size dummies. The results indicate that cash flow is not strongly associated with growth opportunities among large firms. This piece of evidence thus does not support an explanation for the large investment-cash-flow sensitivity for large non-state firms without government connection based on spurious correlation.

Third, Table 14 offers further checks. For each size category, we offer four sets of results: (i) the same as the base specification without the two proxies for growth opportunities; (ii) the base specification with the proxies added; (iii) the instrumental variable estimate with cash flow treated as endogenous and instrumented by its lagged counterpart; and (iv) the base specification with more controls for the business environment and CEO characteristics, similar to in Table 7. The results indicate that our finding of significantly greater financial constraints for large non-state firms without government connection is robust. Indeed, controlling for growth opportunities makes little difference on the coefficient (0.275 vs 0.280$)$. Adding controls reduces the magnitude by just a little (from 0.28 to 0.25 ). Finally, the IV estimate is especially large for large firms, much larger than for the other size groups ( 0.48 for large, 0.22 for medium, and 0.05 for small).

\section{Conclusion}

In this paper we investigate the linkages between firms’ government connections, capital investment behavior, and financial frictions. Employing a large and representative firm-level data set, we use government appointment of CEOs and state ownership as proxies for firms' government connections, and empirically test whether those connections influence firms' investment and financing conditions. We also examine whether the degree of financial constraints differs across firms of various sizes. 
Our empirical findings suggest that investment in firms with strong government connections is less sensitive to internal cash flows than investment in other firms. In particular, compared to firms with non-government-appointed CEOs, investment in firms with governmentappointed CEOs displays much lower sensitivities to cash flows. This indicates that firms with non-government-appointed CEOs tend to face tighter financial constraints due to their inferior political status in the Chinese credit market. Similarly, and consistent with previous literature using other data sets, investment-cash-flow sensitivities are much higher for non-state domestic firms than for other firms. For state-owned firms, which tend to have better access to external finance, there is not a significant link between cash flows and investment. The CEOs of firms with strong connections to the government are subject to different promotion criteria and thus may tend to maintain stable employment and use resources that would otherwise be spent on investment to seek favors from government officials who have influence over their future career. Consistent with that notion, we also find that investment by firms with strong government connections is less sensitive to access to external finance and to indicators of growth opportunities.

Finally, we find that regardless of their size, investment by non-state Chinese firms is influenced by the availability of internal funds. Financial constraints as reflected in high investment-cash-flow sensitivities appear to be especially severe for large non-state firms without a government connection. We conjecture that this may be explained by the greater financial needs of those firms, the relative incapacity of informal finance to cover their financing needs, and the substantial advantages enjoyed by their main competitive rivals (i.e., large SOEs) in gaining access to credit via state-owned banks and equity markets. Our robustness checks confirm this somewhat surprising result. 
Our findings are unique in light of previous studies, which have not emphasized how CEO characteristics and political connections affect financing conditions in China, especially within the subset of privately-owned firms. And our findings suggest that large, non-state, unconnected firms may be especially financially constrained. The result implies that the Chinese credit market is still strongly driven by political connections, and models that ignore firms' CEO government connections are likely to yield imprecise or even misleading estimates of the effects of cash flows on Chinese investment patterns. Moreover, given rising Chinese wages and the potential for lowcost manufacturing to shift to other low-wage, fast-growing countries such as Vietnam and even some in Africa, the role played by large non-state firms is likely to increase over time. How to support the growth of these high-potential firms via improved access to finance therefore should be a key challenge for China in the coming years. 


\section{References}

Acemouglu, Daron, Simon Johnson, and James Robinson. 2001. "The Colonial Origins of Comparative Development: An Empirical Investigation.” American Economic Review 91, 1369-401.

Allen, Franklin, Jun Qian, Meijun Qian. 2005. "Law, Finance, and Economic Growth in China," Journal of Financial Economics, Vol. 77, pp. 57-116."

Almeida, Heitor, Murillo Campello, and Michael S. Weisbach. 2004. “The Cash Flow Sensitivity of Cash.” Journal of Finance 59, 1777-1803.

Altonji, JG, Elder, TE, and Taber, CR. 2005. "Selection on observed and unobserved variables: Assessing the effectiveness of Catholic schools” Journal of Political Economy 113(1), 151-184.

Angrist, Joshua. 2001. "Estimation of Limited Dependent Variable Models with Dummy Endogenous Regressors: Simple Strategies for Empirical Practice," Journal of Business and Economic Statistics 19(1), 2-16.

Ayyagari, Meghana, Asli Demirguc-Kunt, and Vojislav Maksimovic, 2010. "Formal versus Informal Finance: Evidence from China.” Review of Financial Studies 23(8): 3048-3097.

Ayyagari, Meghana, Asli Demirguc-Kunt, \& Vojislav Maksimovic, 2012. "Financing of firms in developing countries : lessons from research," Policy Research Working Paper Series 6036, The World Bank.

Bai C E, Lu J, Tao Z. 2006. The multitask theory of state enterprise reform: empirical evidence from China. The American Economic Review, 96(2): 353-357.

Beck, Thorsten, Aslı Demirgüç-Kunt, and Vojislav Maksimovic, 2005. "Financial and Legal Constraints to Firm Growth: Does Firm Size Matter?” Journal of Finance 60(1): 137-77.

Beck, Thorsten, Asli Demirguc-Kunt, and Maria Soledad Martinez Peria, 2011. "Bank Financing for SMEs: Evidence across Countries and Bank Ownership Types.” Journal of Financial Services Research, 39(1-2): 35-54.

Berger, Allen N., Iftekhar Hasan, and Mingming Zhou, 2009. "Bank Ownership and Efficiency in China: What Will Happen in the Wrold's largest Nation?” Journal of Banking and Finance, 33(1): 113-130.

Berger, Allen N. and Gregory F. Udell, 2006. “A More Complete Conceptual Framework for SME Finance.” Journal of Banking and Finance, 30(11): 2945-2966.

Berkman, H., R.A. Cole, L.J. Fu. 2010. "Political Connections and Minority-Shareholder Protection: Evidence from Securities-Market Regulation in China.” Journal of Financial and Quantitative Analysis 45(6), 1391-1417.

Bliss, M.A., F.A. Gul. 2012. "Political Connection and Cost of Debt: Some Malaysian Evidence.” Journal of Banking and Finance 36(5), 1520-1527. 
Bond, S., Elston, J. A., Mairesse, J. and Mulkay, B. 2003. “Financial Factors and Investment in Belgium, France, Germany, and the United Kingdom: A Comparison Using Company Panel Data,” Review of Economics and Statistics, 85(1), 153-165.

Boubakri, N., JC Cossett, W Saffar. 2008. "Political Connection of Newly privatized Firms," Journal of Corporate Finance 14(5), 654-673.

Boubakri, N., O. Guedhami, D. Mishra, W. Saffar. 2012. "Political Connections and the Cost of Equity Capital,” Journal of Corporate Finance 18(3), 541-549.

Boyreau-Debray, Genevieve, 2003. "Financial Intermediation and Growth: Chinese Style,” World Bank Policy Research Working Paper 3027.

Boyreau-Debray, Genevieve, and Sheng-Jin Wei, 2005. "Pitfalls of a State-dominated Financial System: The Case of China,” NBER working paper 11214. Brandt, Loren \& Li, Hongbin, 2003. "Bank discrimination in transition economies: ideology, information, or incentives?" Journal of Comparative Economics.

Brown, James R., Steven M. Fazzari, and Bruce C. Petersen. 2009. "Financing Innovation and Growth: Cash Flow, External Equity, and the 1990s R\&D Boom.” Journal of Finance 64(1): 151-185.

Brown, James R. and Bruce C. Petersen. 2009. "Why Has the Investment-cash Flow Sensitivity Declined so Sharply? Rising R\&D and Equity Market Developments.” Journal of Banking and Finance 33(5): 971-984.

Bruhn, Miriam, Dean Karlan, and Antoinette Schoar. 2010. "What Capital is Missing in Developing Countries?” American Economic Review: Papers \& Proceedings, 100(2): 629-633.

Cai, Hongbin, Hanming Fang, Lixin Colin Xu. 2011. "Eat, Drink, Firms, Government: An Investigation of Corruption from Entertainment and Travel Costs of Chinese Firms.” Journal of Law and Economics 54, 55-78.

Cao, J., Lemmon, M., Pan, X., Tian, G., 2009. “Political Promotion, CEO Compensation, and Their Effect on Firm Performance.” Working paper.

Calomiris, C.W., R. Fisman, Y.X. Wang. 2010. "Profiting from Government Stakes in a Command Economy: Evidence from Chinese Asset Sales.” Journal of Financial Economics 96(3), 399-412.

Chan, K.S., V.Q.T. Dang, and I.K.M. Yan. 2012. “Chinese Firms’ Political Connection, Ownership, and Financing Constraints,” Economics Letters 115(2), 164-167.

Chaney, Paul K., Mara Faccio, and David C. Parsley. 2011. "The quality of accounting information in politically connected firms", Journal of Accounting and Economics, February 2011, vol. 51(1-2), 58-76.

Chen, Huafeng (Jason) and Shaojun (Jenny) Chen, 2012. "Investment-Cash Flow Sensitivity Cannot be a Good Measure of Financial Constraints: Evidence from the Time Series.” Journal of Financial Economics 103(2): 393-410. 
Chen M. 2008. "Financial Constraints to the Investment of Chinese Listed Firms Across Firm Characteristics," The University of Nottingham Discussion Paper.

Chen, T. 2014. "Institutions, Board Structure, and Corporate Performance: Evidence from Chinese Firms.” Journal of Corporate Finance, Forthcoming.

Chow, C. K. and Fung, M. K. Y. 1998. “Ownership Structure, Lending Bias, and Liquidity Constraints: Evidence from Shanghai’s Manufacturing Sector,” Journal of Comparative Economics, 26: 301-316.

Chow, C.K. and Fung, M. K. Y. 2000. "Small businesses and liquidity constraints in financing business investment: evidence from Shanghai’s manufacturing sector.” Journal of Business Venturing, 15, 363-383.

Claessens, S., E. Feijen, L. Laeven. 2008. "Political Connections and Preferential Access to Finance: The Role of Campaign Contribution,” Journal of Financial Economics 88(3), 554-580.

Cleary, S. 1999. “The Relationship between Firm Investment and Financial Status,” Journal of Finance, 54, 673-692

Cleary, Sean, Paul Povel, and Michael Raith. 2007. “The U-Shaped Investment Curve: Theory and Evidence.” Journal of Financial and Quantitative Analysis 42(1): 1-40.

Cooper, M.J., H. Gulen, A.V. Ovtchinnikov. 2010. “Corporate Political Contributions and Stock Returns.” Journal of Finance 65(2), 687-724.

Cull, Robert, and Lixin Colin Xu, 2003. "Who Gets Credit? The Behavior of Bureaucrats and State Banks in Allocating Credit to Chinese State-owned Enterprises,” Journal of Development Economics 71(2): 533-559.

Cull, Robert, and Lixin Colin Xu. 2005. "Institutions, Ownership, and Finance: The Determinants of Investment among Chinese Firms,” Journal of Financial Economics 77, 117-146.

Cull, Robert, Lixin Colin Xu, Tian Zhu. 2009. "Formal Finance and Trade Credit During China's Transition," Journal of Financial Intermediation 18(2):173-192.

Dethier, Jean-Jacques, Maximilian Hirn, and Stephane Straub. 2011. "Explaining Enterprise Performance in Developing Countries with Business Climate Survey Data.” World Bank Research Observer 26, 258-309.

Dollar, David, and Shang-Jin Wei. 2007. "Das (Wasted) Capital: Firm Ownership and Investment Efficiency in China.” IMF Working Paper 07/09. Washington, DC.

Du, J., S. Girma. 2010. "Red Capitalists: Political Connections and Firm Performance in China.” Kyklos 63(4), 530-545.

Faccio, Mara. 2006. “Politically connected firms.” American Economic Review 96(1), 369-386.

Faccio, Mara, John J. McConnell, and Ronald W. Masulis, 2006. "Political connections and corporate bailouts”, Journal of Finance, vol. 61(6), 2597-2635. 
Faccio, Mara, and David C. Parsley. 2009. "Sudden deaths: Taking stock of geographic ties", Journal of Financial and Quantitative Analysis 33(3): 683-718.

Faccio, Mara. 2010. "Differences between politically connected and non-connected firms: A cross country analysis”, Financial Management, vol. 39(3), 905-927.

Fan, Joseph P.H., T.J. Wong, Tianyu Zhang. 2007. "Politically connected CEOs, corporate governance, and Post-IPO performance of China's newly partially privatized firms.” Journal of Financial Economics 84, 330-357.

Fan, Joseph P.H., O.M. Rui, M.X. Zhao. 2008. "Public Governance and Corporate Governance: Evidence from Corruption Cases,” Journal of Comparative Economics 36(3), 343-364.

Farre-Mensa, Joan and Alexander Ljunqvist, 2013. "Do Measures of Financial Constraints Measure Financial Constraints?” Harvard Business School, mimeo. Available at SSRN: http://ssrn.com/abstract=2338575 or http://dx.doi.org/10.2139/ssrn.2338575

Farrell, Diana, and Susan Lund, 2006. “Putting China’s Capital to Work.” Far Eastern Economic Review, 169: 5-10.

Fazzari, S., G. Hubbard, and B. Petersen. 1988, "Financing constraints and corporate Investment," Brookings Papers on Economic Activity, 19, pp. 141-195.

Fazzari, S., G. Hubbard, and B. Petersen. 2000. "Investment-Cash Flow Sensitivities are Useful: A Comment on Kaplan and Zingales," Quarterly Journal of Economics, volume 115 (May, 2000), 695-705.

Fisman, Raymond. 2001. "Estimating the Value of Political Connections.” American Economic Review, Vol. 91, No. 4, (Sep., 2001), pp. 1095-1102.

Francis, B.B., I. Hasan, X. Sun. 2009. "Political Connections and the Process of Going Public: Evidence from China.” Journal of International Money and Finance 28(4), 696-719.

Goldman, E., J. Rocholl, J. So. 2009. “Do Politically Connected Boards Affect Firm Value?” Review of Financial Study 22(6), 2331-2360.

Gordon, R. H. and W. Li. 2003. "Government as a Discriminating Monopolist in the Financial Market: The Case of China,” Journal of Public Economics, 87:283-312

Gordon, R. H. and W. Li. 2009. "Tax Structures in Developing Countries: Puzzles and Possible Explanations,” Journal of Public Economics, 93: 855-866

Gordon, R. H., and W. Li. 2011. "Provincial and Local Governments in China: Fiscal Institutions and Government Behavior," in "Capitalizing China," National Bureau of Economic Research and University of Chicago Press

Guariglia, Alessandra, Xiaoxuan Liu, and Lina Song. 2011. "Internal Finance and Growth: Microeconometric Evidence on Chinese Firms.” Journal of Development Economics 96(1): 79-94. 
Harrison, Ann, Justin Y. Lin, Lixin Colin Xu. Forthcoming. "Explaining Africa’s (Dis)advantage." World Development.

Héricourt, J. and S. Poncet. 2009. "FDI and credit constraints: firm level evidence in China". Economic Systems, 33, 1-21.

Hoshi, T., Kashyap, A. and Scharfstein, D. 1991, "Corporate Structure, Liquidity and Investment: Evidence from Japanese Industrial Groups,” Quarterly Journal of Economics, Vol. 106, No. 1, 33-60.

Hsu, Berry Fong Chong, and Q. Wan, 2004. "Enhancing Competitiveness Of China’s Banks Through Disposing Non-performance Loans By Asst Management Companies.” Chinese Law and Government, 37(6): 1-66.

Huang, Yasheng. 2003. Selling China: Foreign Direct Investment During the Reform Era. New York: Cambridge University Press.

Hubbard, R. G. 1998, “Capital Market Imperfections and Investment.” Journal of Economic Literature, 36 (1), pp. 193-225.

Jiang, F. and K.A. Kim. 2014. “Corporate governance in China: A modern perspective.” Journal of Corporate Finance, Forthcoming.

Jiang, G., P. Rao, and H. Yue. 2014. "Tunneling through Non-Operational Fund Occupancy: An Investigation Based on Officially Identified Activities.” Journal of Corporate Finance, Forthcoming.

Johnson, S., T. Mitton. 2003. “Cronyism and Capital Control: Evidence from Malaysia.” Journal of Financial Economics 67(2), 351-382.

Kaplan, S. and Zingales, L. 1997. "Do investment-cash flow sensitivities provide useful measures of financing constraints?” Quarterly Journal of Economics, 112, 169-215.

Kaplan, S. and Zingales, L. 2000. "Investment-Cash Flow Sensitivities Are Not Valid Measures of Financing Constraints.” Quarterly Journal of Economics, 115, 707-712.

Knack, Stephen, and Philip Keefer. 1995. "Institutions and Economic Performance: CrossCountry Tests Using Alternative Institutional Measures.” Economics and Politics 7(3), 207-28.

La Porta, Rafael, Florencio Lopez-de-Silanes, Andrei Shleifer, and Robert Vishny. 1997. "Legal Determinants of External Finance.” Journal of Finance 52(3), 1131-50.

—. 1998. "Law and Finance.” Journal of Political Economy 106(6), 1113-55.

_. 2000. "Investor Protection and Corporate Governance.” Journal of Financial Economics 58, 3-27.

Li, H.B., L.S. Meng, Q. Wang, and L.A. Zhou. 2008. "Political Connections, Financing and Firm Performance: Evidence from Chinese Private Firms.” Journal of Development Economics 87(2), 283-299. 
Lin, K. J., J. Tan, L. Zhao, and K. Karim. 2014. "In the Name of Charity: Political Connections and Strategic Corporate Social Responsibility in a Transition Economy.” Journal of Corporate Finance, Forthcoming.

Lin, Yi-min, and Tian Zhu. 2001. "Ownership Restructuring in Chinese State Industry: An Analysis of Evidence on Initial Organizational Changes”, China Quarterly, 166, 305-341.

Luez, C., F. Oberholzer-Gee. 2006. "Political Relationships, Global Financing, and Corporate Transparency: Evidence from Indonesia.” Journal of Financial Economics 81(2), 411439.

McGregor, Richard. 2010. The Party: The Secret World of China's Communist Rulers. New York: Harper Collins Press.

Moshirian, Fariborz, and Alexander Vadilyev, 2013. “Global Financial Management and Financial Constraints.” University of New South Wales, mimeo.

Poncet, Sandra, Walter Steingress, and Hylke Vandenbussche, 2010. "Financial Constraints in China: Firm-level Evidence.” China Economic Review 21(3): 411-422.

Qian, M. and B. Young. 2014. “Bank Financing and Corporate Governance.” Journal of Corporate Finance, Forthcoming.

Stein, J. 2003. “Agency, Information and Corporate Investment.” forthcoming in the Handbook of the Economics of Finance, edited by George Constantinides, Milton Harris, and Rene Stulz.

Wang, Xiaozu, Lixin Colin Xu, and Tian Zhu. 2004. "State-Owned Enterprises Going Public The Case of China.” Economics of Transition 12(3): 467-487.

Weisbach, Michael S. 1995. “CEO Turnover and the Firm’s Investment Decisions.” Journal of Financial Economics 37, 159-188.

World Bank and the Development Research Center of the State Council, P. R. China. 2013. China 2030: Building a Modern, Harmonious, and Creative Society. Washington, DC: World Bank.

Wu, W.F., C.F. Wu, and O.M. Rui. “Ownership and the Value of Political Connections: Evidence from China.” European Financial Management 18(4), 695-729.

Wu, W.F., C.F. Wu, C.Y. Zhou, J. Wu. "Political Connections, Tax Benefits and Firm Performance: Evidence from China,” Journal of Accounting and Public Policy 31(3), 277-300.

$\mathrm{Xu}$, Lixin Colin. 2011. "The Effects of Business Environments on Development: A Survey of New Firm-Level Evidence,” World Bank Research Observer 26 (2), 310-340.

Xu, Lixin Colin, Tian Zhu, Yi-Min Lin. 2005. “Politician Control, Agency Problems, and Ownership Reform: Evidence from China” Economics of Transition 13(1), 1-24.

Zhu, Tian. 1999. “China’s Corporatization Drive: An Evaluation and Policy Implications,” Contemporary Economic Policy, 17(4), 530-539. 
Table 1. Summary Statistics for the Pooled Sample.

\begin{tabular}{lccccc}
\hline & $\mathrm{N}$ & mean & sd & min & $\max$ \\
I/lagged K & 11,659 & 0.338 & 0.882 & 0.000 & 7.086 \\
Ln(GDP per capita) & 11,699 & 8.992 & 0.649 & 7.517 & 10.511 \\
Ln(city population) & 11,699 & 6.229 & 0.560 & 4.840 & 7.927 \\
Firm age & 11,694 & 13.652 & 13.545 & 3.000 & 140.000 \\
Non-state & 10,756 & 0.780 & 0.414 & 0.000 & 1.000 \\
Foreign & 10,756 & 0.121 & 0.326 & 0.000 & 1.000 \\
Loan & 11,697 & 0.595 & 0.491 & 0.000 & 1.000 \\
Tradecredit & 11,699 & 0.086 & 0.195 & 0.000 & 1.000 \\
UCA & 11,563 & 0.109 & 1.638 & -15.830 & 1.000 \\
Sales/lagged K & 11,566 & 6.620 & 13.646 & 0.004 & 162.523 \\
CF/lagged K & 11,404 & 0.533 & 1.279 & -0.549 & 15.038 \\
Lagged sales growth & 11,438 & 0.608 & 1.425 & -1.628 & 15.887 \\
Tobin’s Q & & 1.205 & 0.138 & 0.909 & 1.831 \\
\hline & & & & & \\
\hline
\end{tabular}


Table 2. Summary Statistics by CEO appointment status

\begin{tabular}{|c|c|c|c|c|c|c|c|c|}
\hline & \multicolumn{8}{|c|}{ Pooled } \\
\hline & \multicolumn{3}{|c|}{ Non-gov-appointed CEO } & \multicolumn{3}{|c|}{ Government-appointed CEO } & \multirow[t]{2}{*}{ Gov-Non } & \multirow[t]{2}{*}{ t-stat } \\
\hline & $\mathrm{N}$ & mean & sd & $\mathrm{N}$ & mean & sd & & \\
\hline I/lagged K & 10,263 & 0.360 & 0.921 & 1,365 & 0.179 & 0.487 & -0.181 & 7.138 \\
\hline Ln(GDP per capita) & 10,296 & 9.005 & 0.652 & 1,372 & 8.892 & 0.619 & -0.113 & 6.090 \\
\hline Ln(city population) & 10,296 & 6.222 & 0.561 & 1,372 & 6.278 & 0.546 & 0.056 & 3.480 \\
\hline Firm age & 10,291 & 12.002 & 11.714 & 1,372 & 25.987 & 18.937 & 13.985 & 38.083 \\
\hline Non-state & 9,383 & 0.818 & 0.386 & 1,343 & 0.517 & 0.500 & -0.300 & 25.610 \\
\hline Foreign & 9,383 & 0.134 & 0.340 & 1,343 & 0.030 & 0.170 & -0.104 & 10.990 \\
\hline loan & 10,295 & 0.600 & 0.490 & 1,371 & 0.562 & 0.496 & -0.037 & 2.640 \\
\hline Trade credit & 10,296 & 0.087 & 0.197 & 1,372 & 0.080 & 0.174 & -0.008 & 1.345 \\
\hline UCA & 10,182 & 0.108 & 1.649 & 1,350 & 0.114 & 1.560 & 0.006 & 0.117 \\
\hline Sales/lagged K & 10,178 & 7.031 & 14.128 & 1,357 & 3.560 & 8.697 & -3.471 & 8.829 \\
\hline CF/lagged K & 10,054 & 0.642 & 1.461 & 1,353 & 0.356 & 1.102 & -0.286 & 6.942 \\
\hline Lagged sales growth & 10,032 & 0.560 & 1.314 & 1,342 & 0.326 & 0.942 & -0.234 & 6.301 \\
\hline \multirow[t]{4}{*}{ Tobin’s Q } & 10,296 & 1.205 & 0.141 & 1,372 & 1.207 & 0.110 & 0.002 & 0.515 \\
\hline & \multicolumn{8}{|c|}{ Nonstate Domestic Firms Only } \\
\hline & \multicolumn{3}{|c|}{ Non-gov-appointed CEO } & \multicolumn{3}{|c|}{ Government-appointed CEO } & Gov-Non & t-stat \\
\hline & $\mathrm{N}$ & mean & sd & $\mathrm{N}$ & mean & sd & & \\
\hline I/lagged K & 7,651 & 0.369 & 0.943 & 691 & 0.227 & 0.627 & -0.141 & 3.865 \\
\hline Ln(GDP per capita) & 7,674 & 8.902 & 0.607 & 695 & 8.916 & 0.630 & 0.014 & 0.579 \\
\hline Ln(city population) & 7,674 & 6.210 & 0.551 & 695 & 6.239 & 0.568 & 0.029 & 1.320 \\
\hline Firm age & 7,670 & 11.504 & 11.144 & 695 & 18.901 & 15.868 & 7.397 & 16.083 \\
\hline loan & 7,673 & 0.605 & 0.489 & 695 & 0.580 & 0.494 & -0.026 & 1.323 \\
\hline Trade credit & 7,674 & 0.077 & 0.173 & 695 & 0.078 & 0.172 & 0.001 & 0.137 \\
\hline UCA & 7,586 & 0.039 & 1.711 & 681 & 0.058 & 1.655 & 0.020 & 0.289 \\
\hline Sales/lagged K & 7,587 & 7.189 & 14.382 & 684 & 4.201 & 7.838 & -2.989 & 5.363 \\
\hline CF/lagged K & 7,496 & 0.636 & 1.418 & 685 & 0.472 & 1.354 & -0.164 & 2.909 \\
\hline Lagged sales growth & 7,486 & 0.567 & 1.300 & 683 & 0.403 & 1.216 & -0.163 & 3.157 \\
\hline Tobin's Q & 7,674 & 1.198 & 0.134 & 695 & 1.193 & 0.101 & -0.005 & 0.896 \\
\hline
\end{tabular}


Table 3. Summary Statistics by Firm Size

\begin{tabular}{|c|c|c|c|c|c|c|c|c|c|c|}
\hline & \multicolumn{10}{|c|}{ Pooled } \\
\hline & \multirow[b]{2}{*}{ Mean } & \multirow{2}{*}{$\begin{array}{c}\text { small } \\
\text { SD }\end{array}$} & \multicolumn{2}{|c|}{ medium } & \multicolumn{2}{|c|}{ large } & \multirow[t]{2}{*}{ med - sml } & \multirow[t]{2}{*}{$\mathbf{t}$} & \multirow[t]{2}{*}{ large-small } & \multirow[t]{2}{*}{$\mathbf{t}$} \\
\hline & & & Mean & SD & Mean & SD & & & & \\
\hline I/lagged K & 0.527 & 1.315 & 0.295 & 0.747 & 0.239 & 0.469 & -0.232 & 10.491 & -0.287 & 11.115 \\
\hline Ln(GDP per capita) & 8.877 & 0.631 & 8.930 & 0.623 & 9.231 & 0.659 & 0.054 & 3.794 & 0.354 & 20.972 \\
\hline Ln(city population) & 6.158 & 0.580 & 6.211 & 0.541 & 6.335 & 0.561 & 0.053 & 4.222 & 0.178 & 11.895 \\
\hline Firm age & 9.716 & 8.294 & 13.179 & 12.284 & 18.563 & 17.997 & 3.463 & 13.750 & 8.848 & 24.130 \\
\hline Non-state & 0.913 & 0.281 & 0.794 & 0.404 & 0.614 & 0.487 & -0.119 & 13.820 & -0.299 & 27.772 \\
\hline Foreign & 0.045 & 0.208 & 0.114 & 0.318 & 0.211 & 0.408 & 0.069 & 10.320 & 0.166 & 18.937 \\
\hline Loan & 0.367 & 0.482 & 0.614 & 0.487 & 0.785 & 0.411 & 0.247 & 22.429 & 0.417 & 35.610 \\
\hline Tradecredit & 0.076 & 0.179 & 0.082 & 0.185 & 0.106 & 0.225 & 0.006 & 1.496 & 0.031 & 5.748 \\
\hline UCA & 0.019 & 2.191 & 0.100 & 1.559 & 0.214 & 1.056 & 0.081 & 1.963 & 0.195 & 4.316 \\
\hline Sales/lagged K & 14.708 & 22.729 & 4.619 & 8.135 & 2.836 & 4.783 & -10.089 & 30.133 & -11.872 & 27.603 \\
\hline CF/lagged K & 1.106 & 2.227 & 0.508 & 1.153 & 0.342 & 0.602 & -0.598 & 16.314 & -0.764 & 17.824 \\
\hline Lagged sales growth & 0.640 & 1.538 & 0.506 & 1.199 & 0.480 & 1.137 & -0.134 & 4.404 & -0.160 & 4.467 \\
\hline Tobin's Q & 1.206 & 0.147 & 1.206 & 0.138 & 1.204 & 0.129 & -0.000 & 0.086 & -0.002 & 0.573 \\
\hline Real capital stock & 1.483 & 3.548 & 18.161 & 26.716 & 547.504 & 3241.857 & 16.677 & 33.590 & 546.021 & 9.103 \\
\hline \multirow[t]{4}{*}{ Real sales } & 14.600 & 123.824 & 65.646 & 461.105 & 858.426 & 2509.909 & 51.047 & 5.879 & 843.827 & 18.151 \\
\hline & \multicolumn{10}{|c|}{ Non-State Domestic Firms Only } \\
\hline & small & & medium & & large & & med - small & $\mathbf{t}$ & large-small & $\mathbf{t}$ \\
\hline & Mean & SD & Mean & SD & Mean & SD & & & & \\
\hline I/lagged K & 0.515 & 1.291 & 0.305 & 0.769 & 0.246 & 0.450 & -0.210 & 8.345 & -0.269 & 8.091 \\
\hline Ln(GDP per capita) & 8.848 & 0.613 & 8.857 & 0.586 & 9.112 & 0.617 & 0.009 & 0.569 & 0.264 & 13.487 \\
\hline Ln(city population) & 6.161 & 0.569 & 6.210 & 0.538 & 6.301 & 0.549 & 0.049 & 3.540 & 0.141 & 7.893 \\
\hline Firm age & 9.333 & 7.681 & 12.069 & 11.273 & 16.579 & 16.156 & 2.735 & 10.765 & 7.246 & 19.351 \\
\hline Loan & 0.372 & 0.483 & 0.645 & 0.479 & 0.848 & 0.359 & 0.273 & 22.551 & 0.476 & 34.100 \\
\hline Tradecredit & 0.073 & 0.175 & 0.075 & 0.168 & 0.088 & 0.183 & 0.002 & 0.351 & 0.015 & 2.674 \\
\hline UCA & 0.020 & 2.148 & 0.030 & 1.628 & 0.099 & 1.016 & 0.010 & 0.212 & 0.079 & 1.388 \\
\hline Sales/lagged K & 14.270 & 22.086 & 4.479 & 7.447 & 2.461 & 3.193 & -9.791 & 26.359 & -11.809 & 21.449 \\
\hline CF/lagged K & 1.080 & 2.137 & 0.486 & 1.042 & 0.314 & 0.413 & -0.594 & 15.127 & -0.766 & 14.290 \\
\hline Lagged sales growth & 0.625 & 1.498 & 0.546 & 1.257 & 0.462 & 1.026 & -0.079 & 2.298 & -0.163 & 3.820 \\
\hline Tobin’s Q & 1.201 & 0.139 & 1.198 & 0.130 & 1.191 & 0.121 & -0.003 & 1.016 & -0.010 & 2.358 \\
\hline Real capital stock & 1.463 & 3.652 & 16.973 & 24.604 & 581.142 & 3599.071 & 15.510 & 31.377 & 579.679 & 8.070 \\
\hline Real sales & 11.636 & 42.036 & 50.693 & 89.761 & 807.198 & 2460.596 & 39.057 & 20.508 & 795.563 & 16.196 \\
\hline
\end{tabular}

Note. Small and large firms are firms with capital stock in the bottom and top quartiles. Medium-sized firms are those in the middle two quartiles in capital stock. Real capital stock and real sales are in million yuan (in 2004 value).

The number of observations differs across columns. For the pooled sample, the number of observations is from 2729-2922 (depending on which variable we refer to) for small firms; 5337-5840 for medium-sized firms; and 26572923 for large firms. For the non-state sample, the number of observations is from 2358-2510 for small firms; $4142-$ 4239 for medium-sized firms; and 1604-1632 for large firms. 
Table 4. The Investment Equation for the Pooled sample

\begin{tabular}{|c|c|c|c|c|c|c|c|c|}
\hline & $\begin{array}{c}\text { tobit } \\
\text { coef/t } \\
(1)\end{array}$ & $\begin{array}{c}\text { OLS } \\
\text { coef/t } \\
(2)\end{array}$ & $\begin{array}{c}\text { tobit } \\
\text { coef/t } \\
(3)\end{array}$ & $\begin{array}{c}\text { OLS } \\
\text { coef/t } \\
(4)\end{array}$ & $\begin{array}{c}\text { OLS+ind } \\
\text { coef/t } \\
(5)\end{array}$ & $\begin{array}{c}\text { IV } \\
\text { coef/t } \\
(6)\end{array}$ & $\begin{array}{c}\text { OLS } \\
\text { coef/t } \\
(7)\end{array}$ & $\begin{array}{c}\text { FE } \\
\text { coef/t } \\
(8)\end{array}$ \\
\hline ln(GDP per capita) & $\begin{array}{r}0.043 \\
(1.406)\end{array}$ & $\begin{array}{r}-0.014 \\
(-0.695)\end{array}$ & $\begin{array}{r}0.035 \\
(1.231)\end{array}$ & $\begin{array}{r}-0.021 \\
(-1.089)\end{array}$ & $\begin{array}{c}-0.037^{*} \\
(-1.946)\end{array}$ & $\begin{array}{r}-0.040 * * \\
(-2.327)\end{array}$ & $\begin{array}{r}-0.019 \\
(-0.984)\end{array}$ & \\
\hline $\ln ($ city pop) & $\begin{array}{r}0.058 * * \\
(2.132)\end{array}$ & $\begin{array}{r}0.021 \\
(1.427)\end{array}$ & $\begin{array}{r}0.054 * * \\
(2.108)\end{array}$ & $\begin{array}{r}0.020 \\
(1.362)\end{array}$ & $\begin{array}{r}0.009 \\
(0.612)\end{array}$ & $\begin{array}{r}0.009 \\
(0.581)\end{array}$ & $\begin{array}{r}0.016 \\
(1.091)\end{array}$ & \\
\hline ln(firm age) & $\begin{array}{r}-0.044 * * * \\
(-2.910)\end{array}$ & $\begin{array}{r}-0.048 * * * \\
(-4.554)\end{array}$ & $\begin{array}{r}-0.052 * * * \\
(-3.428)\end{array}$ & $\begin{array}{r}-0.051 * * * \\
(-4.801)\end{array}$ & $\begin{array}{r}-0.055^{* * *} \\
(-4.985)\end{array}$ & $\begin{array}{r}-0.053 * * * \\
(-5.606)\end{array}$ & $\begin{array}{r}-0.051^{* * *} \\
(-4.638)\end{array}$ & \\
\hline Non-state & $\begin{array}{c}0.066^{*} \\
(1.935)\end{array}$ & $\begin{array}{r}0.055^{* *} \\
(2.542)\end{array}$ & $\begin{array}{r}0.044 \\
(1.366)\end{array}$ & $\begin{array}{r}0.042 * * \\
(1.975)\end{array}$ & $\begin{array}{c}0.045 * * \\
(2.053)\end{array}$ & $\begin{array}{r}0.052 * * \\
(2.995)\end{array}$ & $\begin{array}{c}0.039 * \\
(1.909)\end{array}$ & \\
\hline Foreign & $\begin{array}{c}0.082 * * \\
(2.221)\end{array}$ & $\begin{array}{r}0.011 \\
(0.405)\end{array}$ & $\begin{array}{r}0.047 \\
(1.309)\end{array}$ & $\begin{array}{r}-0.014 \\
(-0.545)\end{array}$ & $\begin{array}{r}-0.018 \\
(-0.648)\end{array}$ & $\begin{array}{r}-0.006 \\
(-0.210)\end{array}$ & $\begin{array}{r}-0.023 \\
(-0.879)\end{array}$ & \\
\hline sales/lagged K & $\begin{array}{r}0.008^{* * * *} \\
(5.074)\end{array}$ & $\begin{array}{r}0.008 * * * \\
(6.014)\end{array}$ & $\begin{array}{r}0.011^{* * * *} \\
(6.349)\end{array}$ & $\begin{array}{r}0.010 * * * \\
(6.914)\end{array}$ & $\begin{array}{r}0.010 * * * \\
(6.975)\end{array}$ & $\begin{array}{r}0.011^{* * * *} \\
(5.467)\end{array}$ & $\begin{array}{r}0.011^{* * * *} \\
(6.902)\end{array}$ & $\begin{array}{r}0.043^{* * *} \\
(32.645)\end{array}$ \\
\hline CF/lagged K & $\begin{array}{r}0.107^{* * *} \\
(5.182)\end{array}$ & $\begin{array}{r}0.089 * * * \\
(4.881)\end{array}$ & $\begin{array}{r}0.129 * * * \\
(5.900)\end{array}$ & $\begin{array}{r}0.107^{* * *} \\
(5.510)\end{array}$ & $\begin{array}{r}0.105^{* * *} \\
(5.386)\end{array}$ & $\begin{array}{r}0.090^{* * *} \\
(3.856)\end{array}$ & $\begin{array}{r}0.106^{* * *} \\
(5.400)\end{array}$ & $\begin{array}{r}0.089 * * * \\
(8.780)\end{array}$ \\
\hline Loan & & & $\begin{array}{r}0.289 * * * \\
(11.621)\end{array}$ & $\begin{array}{r}0.155^{* * *} \\
(9.234)\end{array}$ & $\begin{array}{r}0.155^{* * *} \\
(9.020)\end{array}$ & $\begin{array}{r}0.149 * * * \\
(8.767)\end{array}$ & $\begin{array}{r}0.165^{* * *} \\
(9.790)\end{array}$ & \\
\hline Trade credit & & & $\begin{array}{r}0.103 * * \\
(2.103)\end{array}$ & $\begin{array}{c}0.079 * \\
(1.899)\end{array}$ & $\begin{array}{c}0.071 * \\
(1.716)\end{array}$ & $\begin{array}{r}0.058 \\
(1.482)\end{array}$ & $\begin{array}{c}0.076 * \\
(1.755)\end{array}$ & \\
\hline UCA & & & $\begin{array}{r}0.044^{* * *} \\
(4.432)\end{array}$ & $\begin{array}{r}0.032^{* * *} \\
(4.475)\end{array}$ & $\begin{array}{r}0.031^{* * *} \\
(4.570)\end{array}$ & $\begin{array}{r}0.028 * * * \\
(4.248)\end{array}$ & $\begin{array}{r}0.031^{* * *} \\
(4.399)\end{array}$ & \\
\hline Lagged sale growth & & & & & & & $\begin{array}{r}0.019 * * * \\
(3.095)\end{array}$ & \\
\hline Tobin's Q & & & & & & & $\begin{array}{r}0.247 * * * \\
(3.721)\end{array}$ & \\
\hline Ind $\mathrm{Q}$ & & & & & & & & $\begin{array}{r}0.158 * * * \\
(3.205)\end{array}$ \\
\hline $\begin{array}{l}\text { Number of } \\
\text { observations }\end{array}$ & 10,283 & 10,283 & 10,207 & 10,207 & 10,207 & 10,032 & 9,982 & 22,688 \\
\hline Adjusted R2 & 0.020 & 0.061 & 0.031 & 0.079 & 0.085 & 0.080 & 0.085 & -0.744 \\
\hline
\end{tabular}


Table 5. Investment cash-flow sensitivity by various ways to distinguish financially constrained firms

\begin{tabular}{|c|c|c|c|c|c|c|c|c|c|c|}
\hline & $\begin{array}{l}\text { Non-severe } \\
\text { constraint in } \\
\text { financing access }\end{array}$ & $\begin{array}{c}\text { Severe } \\
\text { constraint in } \\
\text { financing } \\
\text { access }\end{array}$ & $\begin{array}{l}\text { Non-severe } \\
\text { constraint in } \\
\text { financing cost }\end{array}$ & $\begin{array}{c}\text { Severe } \\
\text { constraint in } \\
\text { financing } \\
\text { cost }\end{array}$ & $\begin{array}{c}\text { More } \\
\text { difficult to } \\
\text { obtain } \\
\text { loans since } \\
\text { fin crunch } \\
\text { in } 2003\end{array}$ & $\begin{array}{l}\text { Not more } \\
\text { difficult to } \\
\text { obtain } \\
\text { loans since } \\
\text { fin crunch } \\
\text { in } 2003\end{array}$ & $\begin{array}{l}\text { Low } \\
\text { property } \\
\text { rights } \\
\text { protection }\end{array}$ & $\begin{array}{l}\text { High } \\
\text { property } \\
\text { rights } \\
\text { protection }\end{array}$ & $\begin{array}{l}\text { Age } 8 \text { or } \\
\text { younger }\end{array}$ & $\begin{array}{l}\text { Age } 9 \text { or } \\
\text { older }\end{array}$ \\
\hline \multirow[t]{2}{*}{$\ln$ (firm age) } & $-0.048^{* * *}$ & $-0.065^{* * *}$ & $-0.050 * * *$ & $-0.067 * * *$ & $-0.055^{* * *}$ & $-0.050 * * *$ & $-0.059 * * *$ & $-0.050 * * *$ & -0.057 & $-0.049 * * *$ \\
\hline & $(-3.503)$ & $(-4.181)$ & $(-4.126)$ & $(-2.999)$ & $(-4.316)$ & $(-2.753)$ & $(-4.402)$ & $(-2.905)$ & $(-1.330)$ & $(-2.912)$ \\
\hline \multirow[t]{2}{*}{ Non-state } & 0.040 & $0.059 * *$ & $0.052 * *$ & 0.028 & $0.047 *$ & 0.030 & 0.026 & $0.068^{*}$ & 0.080 & $0.046^{* *}$ \\
\hline & (1.327) & $(2.084)$ & $(2.056)$ & $(0.737)$ & (1.673) & $(0.953)$ & $(0.916)$ & (1.894) & (1.614) & (1.973) \\
\hline \multirow[t]{2}{*}{ Foreign } & -0.036 & 0.079 & -0.021 & 0.095 & 0.008 & -0.043 & -0.016 & -0.018 & 0.049 & -0.045 \\
\hline & $(-0.958)$ & $(1.001)$ & $(-0.666)$ & $(0.813)$ & (0.199) & $(-1.110)$ & $(-0.396)$ & $(-0.400)$ & $(0.778)$ & $(-1.304)$ \\
\hline \multirow[t]{2}{*}{ Loan } & $0.181^{* * *}$ & $0.072^{* *}$ & $0.161 * * *$ & $0.115^{* *}$ & $0.149 * * *$ & $0.151^{* * *}$ & $0.146^{* * *}$ & $0.160^{* * *}$ & $0.196^{* * *}$ & $0.113^{* * *}$ \\
\hline & (9.089) & (2.147) & (8.809) & (2.386) & (7.376) & (5.465) & (6.337) & (6.595) & (6.159) & (5.467) \\
\hline \multirow[t]{2}{*}{ Trade credit } & $0.090^{*}$ & -0.004 & $0.086^{*}$ & -0.018 & 0.064 & 0.076 & 0.078 & 0.059 & 0.100 & 0.050 \\
\hline & (1.797) & $(-0.059)$ & $(1.791)$ & $(-0.198)$ & (1.129) & (1.459) & (1.557) & (0.959) & (1.307) & (1.124) \\
\hline \multirow[t]{2}{*}{ UCA } & $0.027^{* * *}$ & $0.041^{* * *}$ & $0.028^{* * *}$ & $0.048^{* * *}$ & $0.041^{* * *}$ & 0.015 & $0.033^{* * *}$ & $0.030^{* * *}$ & $0.037 * * *$ & $0.026^{* * *}$ \\
\hline & (3.056) & $(4.034)$ & (3.546) & $(4.514)$ & (5.177) & (1.339) & $(4.493)$ & $(2.979)$ & (3.532) & (3.123) \\
\hline \multirow[t]{2}{*}{ sales/lagged K } & $0.011^{* * *}$ & $0.009 * * *$ & $0.010^{* * *}$ & $0.011^{* * *}$ & $0.012^{* * *}$ & $0.010^{* * *}$ & $0.012^{* * *}$ & $0.008^{* * *}$ & $0.011^{* * *}$ & $0.010^{* * *}$ \\
\hline & (5.777) & (3.752) & $(6.233)$ & $(2.858)$ & $(5.200)$ & $(4.279)$ & (5.859) & (3.801) & (5.390) & $(4.247)$ \\
\hline \multirow[t]{2}{*}{ CF/lagged K } & $0.094^{* * *}$ & $0.135^{* * *}$ & $0.098^{* * *}$ & $0.161^{* * *}$ & $0.134^{* * *}$ & $0.062^{* * *}$ & $0.113^{* * *}$ & $0.100^{* * *}$ & $0.120^{* * *}$ & $0.084^{* * *}$ \\
\hline & (4.405) & (3.792) & (4.667) & (3.613) & (5.095) & (3.204) & $(4.401)$ & (3.730) & $(4.954)$ & (2.695) \\
\hline $\begin{array}{l}\text { Number of } \\
\text { observations }\end{array}$ & 7,563 & 2,644 & 8,751 & 1,456 & 6,337 & 3,870 & 5,129 & 5,078 & 4,847 & 5,360 \\
\hline Adjusted R2 & 0.084 & 0.093 & 0.083 & 0.107 & 0.098 & 0.067 & 0.103 & 0.070 & 0.090 & 0.074 \\
\hline
\end{tabular}

Not reported are coefficients of area dummies and industry dummies, and of city population and city GDP per capita.

ICF sensitivity is 0.144 for group companies, and 0.089 for non-group companies. 
Table 6. A few checks for key results

\begin{tabular}{|c|c|c|c|}
\hline & Base & Only positive cash flows & $\begin{array}{c}\text { Physical plus R\&D investment } \\
\text { over lagged } \mathrm{K}\end{array}$ \\
\hline & (1) & (2) & $(3)$ \\
\hline \multirow[t]{2}{*}{ In(firm age) } & $-0.055^{\star \star \star}$ & $-0.057^{\star \star \star}$ & $-0.063^{\star \star \star}$ \\
\hline & $(-4.985)$ & $(-4.528)$ & $(-5.707)$ \\
\hline \multirow[t]{2}{*}{ Non-state } & $0.045^{\star \star}$ & 0.041 & $0.047^{\star *}$ \\
\hline & $(2.053)$ & $(1.482)$ & $(1.998)$ \\
\hline \multirow[t]{2}{*}{ Foreign } & -0.018 & -0.033 & -0.032 \\
\hline & $(-0.648)$ & $(-1.006)$ & $(-1.033)$ \\
\hline \multirow[t]{2}{*}{ Loan } & $0.155^{\star \star \star}$ & $0.176^{\star \star \star}$ & 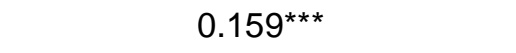 \\
\hline & $(9.020)$ & $(9.081)$ & $(8.949)$ \\
\hline \multirow[t]{2}{*}{ Trade credit } & $0.071^{*}$ & $0.084^{\star}$ & 0.065 \\
\hline & $(1.716)$ & $(1.864)$ & $(1.560)$ \\
\hline \multirow[t]{2}{*}{ UCA } & $0.031^{\star \star *}$ & $0.033^{\star \star \star}$ & $0.026^{\star \star \star}$ \\
\hline & $(4.570)$ & $(4.346)$ & $(3.455)$ \\
\hline \multirow[t]{2}{*}{ sales/lagged K } & $0.010^{\star \star \star}$ & $0.010^{\star \star \star}$ & $0.012^{\star \star \star}$ \\
\hline & $(6.975)$ & $(6.255)$ & $(7.391)$ \\
\hline \multirow[t]{2}{*}{ CFllagged K } & $0.105^{\star \star \star}$ & $0.111 * * *$ & $0.113^{\star * *}$ \\
\hline & $(5.386)$ & $(5.427)$ & $(5.707)$ \\
\hline $\begin{array}{l}\text { Number of } \\
\text { observations }\end{array}$ & 10,207 & 8,727 & 10,142 \\
\hline Adjusted R2 & 0.085 & 0.086 & 0.096 \\
\hline
\end{tabular}

Not reported are coefficients of area dummies and industry dummies, and of city population and city GDP per capita. 
Table 7. The Investment Equation with Sensitivity Checks

\begin{tabular}{|c|c|c|c|c|c|c|}
\hline & OLS & OLS & OLS & OLS & OLS & OLS \\
\hline & (1) & $(2)$ & (3) & (4) & (5) & (6) \\
\hline \multirow[t]{2}{*}{ Loan } & $0.155^{* * *}$ & $0.155^{* * *}$ & $0.155^{* * *}$ & $0.140 * * *$ & $0.155^{* * *}$ & $0.138 * * *$ \\
\hline & (9.234) & (9.224) & (9.149) & (8.342) & (9.171) & (8.102) \\
\hline \multirow[t]{2}{*}{ Trade credit } & $0.079 *$ & $0.079 *$ & $0.089 * *$ & $0.073^{*}$ & $0.080^{*}$ & $0.081^{* *}$ \\
\hline & (1.899) & (1.899) & (2.134) & (1.813) & (1.918) & $(1.981)$ \\
\hline \multirow[t]{2}{*}{ UCA } & $0.032 * * *$ & $0.032 * * *$ & $0.032 * * *$ & $0.033^{* * *}$ & $0.032 * * *$ & $0.033^{* * *}$ \\
\hline & $(4.475)$ & (4.493) & (4.484) & (4.455) & (4.477) & (4.501) \\
\hline \multirow[t]{2}{*}{ sales/lagged K } & $0.010 * * *$ & $0.010 * * *$ & $0.010 * * *$ & $0.011^{* * *}$ & $0.010 * * *$ & $0.011^{* * *}$ \\
\hline & (6.914) & (6.893) & (6.864) & (6.907) & (6.923) & (6.837) \\
\hline \multirow[t]{2}{*}{ CF/lagged K } & $0.107 * * *$ & $0.106^{* * *}$ & $0.107 * * *$ & $0.110^{* * *}$ & $0.107 * * *$ & $0.110^{* * *}$ \\
\hline & (5.510) & (5.490) & (5.477) & (5.554) & (5.519) & (5.508) \\
\hline \multirow[t]{2}{*}{ Loss of sales due to power outages } & & 0.196 & & & & 0.228 \\
\hline & & $(1.400)$ & & & & $(1.600)$ \\
\hline \multirow{2}{*}{$\begin{array}{l}\text { Loss of sales due to transport } \\
\text { problems }\end{array}$} & & -0.109 & & & & -0.076 \\
\hline & & $(-0.370)$ & & & & $(-0.245)$ \\
\hline \multirow[t]{2}{*}{ Road density } & & -0.115 & & & & 0.175 \\
\hline & & $(-0.226)$ & & & & $(0.349)$ \\
\hline \multirow[t]{2}{*}{ autonomy in investment } & & & 0.036 & & & 0.033 \\
\hline & & & $(1.334)$ & & & $(1.161)$ \\
\hline \multirow[t]{2}{*}{ CEO schooling } & & & & $0.019 * * *$ & & $0.020 * * *$ \\
\hline & & & & (3.791) & & (3.931) \\
\hline \multirow[t]{2}{*}{ CEO appointed by gov’t } & & & & $-0.055^{* *}$ & & $-0.052 * *$ \\
\hline & & & & $(-2.564)$ & & $(-2.400)$ \\
\hline \multirow[t]{2}{*}{ CEO also board chairman } & & & & $0.055^{* * *}$ & & $0.051 * * *$ \\
\hline & & & & $(2.892)$ & & (2.638) \\
\hline \multirow[t]{2}{*}{ CEO wage/worker wage } & & & & 0.002 & & 0.002 \\
\hline & & & & $(1.394)$ & & $(1.410)$ \\
\hline \multirow[t]{2}{*}{ CEO has incentive plans } & & & & 0.071 & & 0.073 \\
\hline & & & & $(1.097)$ & & $(1.121)$ \\
\hline \multirow[t]{2}{*}{ PR protection } & & & & & 0.026 & 0.036 \\
\hline & & & & & $(0.343)$ & $(0.466)$ \\
\hline \multirow[t]{2}{*}{ government help } & & & & & 0.037 & 0.031 \\
\hline & & & & & $(0.727)$ & $(0.595)$ \\
\hline \multirow[t]{2}{*}{ ETC } & & & & & 0.815 & 1.221 \\
\hline & & & & & $(0.383)$ & $(0.582)$ \\
\hline Number of observations & 10,207 & 10,207 & 10,106 & 9,945 & 10,207 & 9,866 \\
\hline Adjusted R2 & 0.079 & 0.079 & 0.080 & 0.084 & 0.079 & 0.084 \\
\hline
\end{tabular}


Table 8. The Investment Equation by Ownership

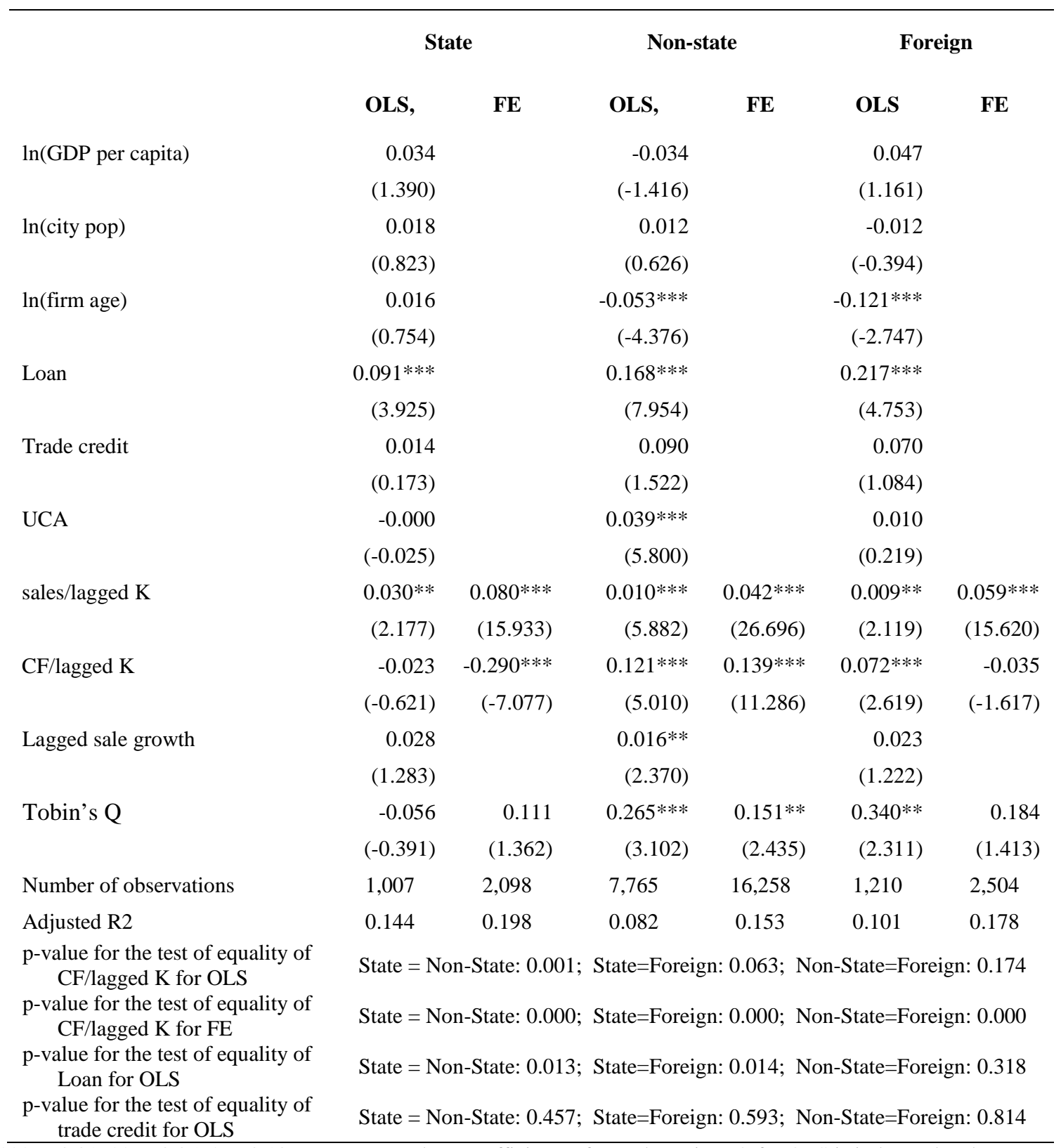

*** $\mathrm{p}<0.01,{ }^{* *} \mathrm{p}<0.05,{ }^{*} \mathrm{p}<0.10$. Not reported are coefficients of area dummies. Q for OLS is industry-level average of $\mathrm{Q}$, and for FE is industry-year level of Q. 
Table 9. The Investment Equation by CEO government connection

\begin{tabular}{|c|c|c|c|c|}
\hline & \multicolumn{2}{|c|}{ Non-government-appointed CEOs } & \multicolumn{2}{|c|}{ Government-appointed CEOs } \\
\hline & OLS & FE & OLS & FE \\
\hline \multirow[t]{2}{*}{ ln(GDP per capita) } & -0.026 & & 0.022 & \\
\hline & $(-1.362)$ & & $(0.710)$ & \\
\hline \multirow[t]{2}{*}{$\ln ($ city pop) } & 0.015 & & 0.013 & \\
\hline & $(0.945)$ & & $(0.485)$ & \\
\hline \multirow[t]{2}{*}{$\ln$ (firm age) } & $-0.003 * * *$ & & -0.000 & \\
\hline & $(-4.806)$ & & $(-0.654)$ & \\
\hline \multirow[t]{2}{*}{ Non-state } & 0.003 & & $0.067 * * *$ & \\
\hline & $(0.104)$ & & $(2.818)$ & \\
\hline \multirow[t]{2}{*}{ Foreign } & $-0.067 *$ & & 0.009 & \\
\hline & $(-1.771)$ & & $(0.161)$ & \\
\hline \multirow[t]{2}{*}{ 1(access to loan) } & $0.175^{* * *}$ & & $0.100 * * *$ & \\
\hline & $(8.812)$ & & $(3.723)$ & \\
\hline \multirow[t]{2}{*}{ trade credit } & $0.093 * *$ & & -0.059 & \\
\hline & (2.039) & & $(-1.051)$ & \\
\hline \multirow[t]{2}{*}{ UCA } & $0.036 * * *$ & & 0.003 & \\
\hline & $(4.915)$ & & $(0.294)$ & \\
\hline \multirow[t]{2}{*}{ sales/lagged K } & $0.011^{* * *}$ & $0.043 * * *$ & 0.008 & $0.068 * * *$ \\
\hline & $(5.923)$ & $(30.438)$ & $(1.164)$ & $(12.941)$ \\
\hline \multirow[t]{2}{*}{ CF/LAGGED K } & $0.111 * * *$ & $0.091 * * *$ & 0.045 & $0.066^{* *}$ \\
\hline & $(5.887)$ & $(8.418)$ & $(1.008)$ & $(2.088)$ \\
\hline \multirow[t]{2}{*}{ Lagged sales growth } & $0.022 * * *$ & & 0.000 & \\
\hline & $(3.279)$ & & $(0.008)$ & \\
\hline \multirow[t]{2}{*}{ Tobin’s Q } & $0.256 * * *$ & $0.155^{* * *}$ & 0.030 & $0.192 * *$ \\
\hline & $(3.381)$ & $(2.814)$ & $(0.388)$ & $(2.134)$ \\
\hline Number of observations & 8,693 & 19,934 & 1,261 & 2,692 \\
\hline Adjusted R2 & 0.084 & 0.144 & 0.049 & 0.133 \\
\hline $\begin{array}{l}\text { p-value for the test of equality of } \\
\text { CF/lagged K for OLS }\end{array}$ & \multicolumn{4}{|c|}{ Non government = government CEO: 0.205} \\
\hline $\begin{array}{l}\text { p-value for the test of equality of } \\
\text { CF/lagged K for FE }\end{array}$ & \multicolumn{4}{|c|}{ Non government $=$ government CEO: 0.655} \\
\hline $\begin{array}{l}\mathrm{p} \text {-value for the test of equality of } \\
\text { Loan for OLS }\end{array}$ & \multicolumn{4}{|c|}{ Non government = government CEO: 0.017} \\
\hline $\begin{array}{l}\mathrm{p} \text {-value for the test of equality of } \\
\text { trade credit for OLS. }\end{array}$ & \multicolumn{4}{|c|}{ Non government = government CEO: 0.032} \\
\hline
\end{tabular}




\section{Table 10. CEO Characteristics by CEO government connection}

\author{
Non-government- \\ appointed CEOs \\ Government- \\ appointed CEOs
}

CEO schooling
CEO wage/worker wage
Dummy: CEO income
directly linked to
operating performance
of the firm
The percent of CEO
income increase if
surpassing
performance threshold

(A)

(B)

$15.317(0.012)$

$6.917(0.038)$

$0.078(0.001)$

$15.704(0.025)$

$5.188(0.080)$

$0.071(0.002)$

$0.118(0.001)$

$0.109(0.003)$
T-test for difference between nongovernment-appointed CEO and government-appointed CEO

$$
(\mathrm{A}-\mathrm{B})
$$

$-0.387(0.034) * * *$

$1.728(0.108) * * *$

$0.007(0.002) * * *$

$0.009(0.003)^{* * *}$

Note. All variables come directly from the survey. 
Table 11. The investment equation by firm size (in capital stock) and firm age: Non-State Domestic Only

\begin{tabular}{|c|c|c|c|}
\hline & \multicolumn{3}{|c|}{ By size } \\
\hline & Small & Medium & Large \\
\hline \multirow[t]{2}{*}{ ln(GDP per capita) } & $-0.101 * *$ & 0.001 & 0.010 \\
\hline & $(-2.009)$ & $(0.037)$ & $(0.361)$ \\
\hline \multirow[t]{2}{*}{$\ln ($ city pop) } & -0.014 & 0.026 & 0.041 \\
\hline & $(-0.297)$ & $(0.983)$ & $(1.529)$ \\
\hline \multirow[t]{2}{*}{$\ln ($ firm age) } & $-0.105^{* * *}$ & $-0.037 * *$ & -0.017 \\
\hline & $(-2.842)$ & $(-2.408)$ & $(-1.449)$ \\
\hline \multirow[t]{2}{*}{ Loan } & $0.309 * * *$ & $0.166^{* * *}$ & 0.047 \\
\hline & $(5.200)$ & $(7.331)$ & $(1.150)$ \\
\hline \multirow[t]{2}{*}{ Trade credit } & 0.237 & 0.024 & 0.042 \\
\hline & (1.495) & $(0.338)$ & $(0.746)$ \\
\hline \multirow[t]{2}{*}{ UCA } & $0.048^{* * *}$ & $0.042^{* * *}$ & $0.029 * *$ \\
\hline & $(4.010)$ & $(4.748)$ & $(2.345)$ \\
\hline \multirow[t]{2}{*}{ sales/lagged K } & $0.009 * * *$ & $0.011^{* *}$ & 0.007 \\
\hline & $(4.310)$ & $(2.540)$ & $(1.377)$ \\
\hline \multirow[t]{2}{*}{ CF/lagged K } & $0.103^{* * *}$ & $0.140^{* * *}$ & $0.252^{* * *}$ \\
\hline & $(3.448)$ & $(3.456)$ & $(6.047)$ \\
\hline \multirow[t]{2}{*}{ Lagged sale growth } & $0.031 *$ & 0.001 & $0.034 * * *$ \\
\hline & $(1.901)$ & $(0.149)$ & (3.257) \\
\hline \multirow[t]{2}{*}{ Tobin’s Q } & $0.364^{*}$ & $0.255^{* *}$ & 0.066 \\
\hline & $(1.886)$ & $(2.342)$ & $(0.817)$ \\
\hline Number of observations & 2,170 & 4,021 & 1,573 \\
\hline Adjusted R2 & 0.082 & 0.077 & 0.075 \\
\hline $\begin{array}{l}\text { p-value for the test of equality of } \\
\text { CF/lagged K for OLS }\end{array}$ & \multicolumn{3}{|c|}{ Small=medium:0.444; small=large:0.004; medium=large:0.046 } \\
\hline $\begin{array}{l}\text { p-value for the test of equality of } \\
\text { Loan for OLS }\end{array}$ & \multicolumn{3}{|c|}{ Small=medium:0.022; small=large:0.0001; medium=large:0.009 } \\
\hline $\begin{array}{l}\mathrm{p} \text {-value for the test of equality of } \\
\text { trade credit for OLS }\end{array}$ & \multicolumn{3}{|c|}{ Small=medium:0.219; small=large:0.233; medium=large:0.839 } \\
\hline
\end{tabular}


Table 12. The investment equation by firm size and CEO government connections: non-state domestic only

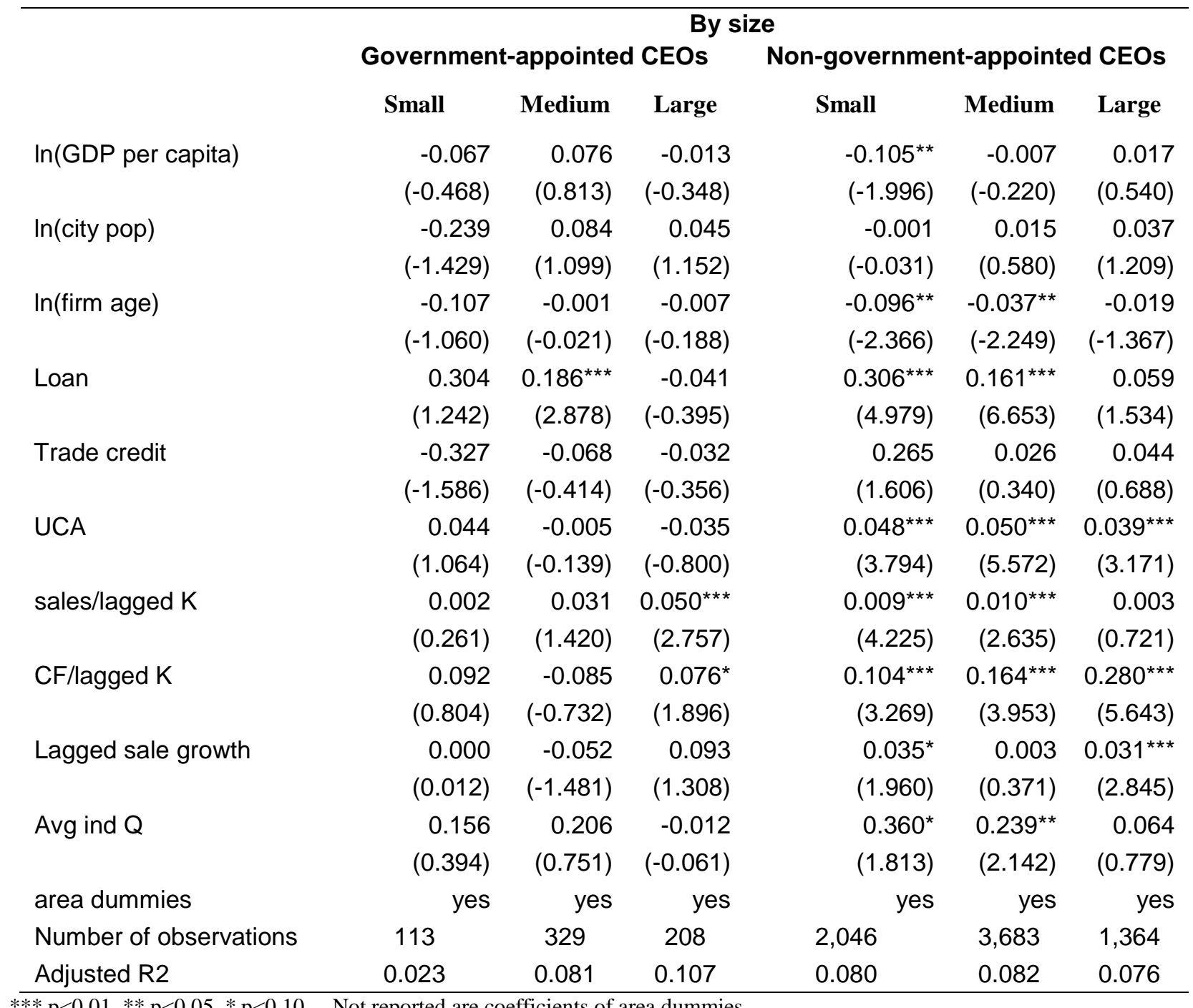


Table 13. Cash flow and growth opportunities

\begin{tabular}{lc}
\hline & coef/t \\
Lagged sale growth & $0.115^{\star \star *}$ \\
& $(5.209)$ \\
Lagged sale growth * medium & $-0.093^{\star \star *}$ \\
& $(-3.316)$ \\
Lagged sale growth * large & $-0.101^{\star *}$ \\
& $(-2.493)$ \\
Avg ind $\mathrm{Q}$ & $0.523^{\star \star *}$ \\
& $(4.285)$ \\
Avg ind $\mathrm{Q} *$ medium & $-0.434^{\star \star *}$ \\
& $(-13.014)$ \\
Avg ind $\mathrm{Q} *$ large & $-0.572^{\star \star *}$ \\
& $(-13.365)$ \\
Intercept & $0.379^{\star \star *}$ \\
& $(2.603)$ \\
Number of observations & 7,330 \\
Adjusted $\mathrm{R} 2$ & 0.047 \\
\hline$* * \mathrm{p}<0.01, * * \mathrm{p}<0.05, * \mathrm{p}<0.10$. &
\end{tabular}


Table 14. Sensitivity check for the by-size results: non-state domestic and non-government-appointed CEOs only

\begin{tabular}{|c|c|c|c|c|c|c|c|c|c|c|c|c|}
\hline & \multicolumn{4}{|c|}{ Small } & \multicolumn{4}{|c|}{ Medium } & \multicolumn{4}{|c|}{ Large } \\
\hline & $\begin{array}{l}\text { without } \\
\text { growth opp }\end{array}$ & base & IV & $\begin{array}{c}\text { More } \\
\text { controls }\end{array}$ & $\begin{array}{l}\text { without } \\
\text { growth opp }\end{array}$ & base & IV & $\begin{array}{c}\text { More } \\
\text { controls }\end{array}$ & $\begin{array}{l}\text { without } \\
\text { growth opp }\end{array}$ & base & IV & $\begin{array}{c}\text { More } \\
\text { controls }\end{array}$ \\
\hline \multirow{2}{*}{$\begin{array}{l}\ln (\text { GDP per } \\
\text { capita) }\end{array}$} & $-0.105^{* *}$ & $-0.105^{* *}$ & $-0.131 * *$ & $-0.127 * *$ & -0.006 & -0.007 & -0.017 & -0.005 & 0.015 & 0.017 & 0.022 & -0.004 \\
\hline & $(-1.963)$ & $(-1.996)$ & $(-2.383)$ & $(-1.997)$ & $(-0.181)$ & $(-0.220)$ & $(-0.600)$ & $(-0.161)$ & $(0.483)$ & $(0.540)$ & $(0.736)$ & $(-0.139)$ \\
\hline \multirow[t]{2}{*}{ ln(city pop) } & -0.012 & -0.001 & -0.011 & -0.038 & 0.022 & 0.015 & 0.027 & 0.040 & 0.039 & 0.037 & 0.035 & 0.003 \\
\hline & $(-0.237)$ & $(-0.031)$ & $(-0.205)$ & $(-0.773)$ & $(0.873)$ & $(0.580)$ & (1.157) & (1.188) & (1.359) & (1.209) & (1.145) & (0.179) \\
\hline \multirow[t]{2}{*}{ ln(firm age) } & $-0.094 * *$ & $-0.096 * *$ & $-0.092 * *$ & $-0.083 * *$ & $-0.032 * *$ & $-0.037 * *$ & $-0.031 * *$ & $-0.032 * *$ & $-0.027 *$ & -0.019 & $-0.024 *$ & $-0.022 *$ \\
\hline & $(-2.389)$ & $(-2.366)$ & $(-2.569)$ & $(-2.065)$ & $(-2.015)$ & $(-2.249)$ & $(-2.174)$ & $(-1.980)$ & $(-1.929)$ & $(-1.367)$ & $(-1.688)$ & $(-1.799)$ \\
\hline \multirow[t]{2}{*}{ Loan } & $0.286^{* * *}$ & $0.306 * * *$ & $0.275^{* * *}$ & $0.273 * * *$ & $0.155^{* * *}$ & $0.161^{* * *}$ & $0.150 * * *$ & $0.141^{* * *}$ & 0.039 & 0.059 & 0.058 & $0.063 *$ \\
\hline & (4.603) & (4.979) & (4.363) & $(4.506)$ & (6.437) & (6.653) & (6.008) & (5.682) & (0.948) & (1.534) & (1.397) & (1.940) \\
\hline \multirow[t]{2}{*}{ Trade credit } & $0.275^{*}$ & 0.265 & 0.201 & $0.272 *$ & 0.026 & 0.026 & 0.031 & 0.011 & 0.042 & 0.044 & 0.060 & 0.055 \\
\hline & (1.693) & (1.606) & (1.334) & (1.652) & $(0.353)$ & $(0.340)$ & $(0.453)$ & (0.153) & $(0.640)$ & (0.688) & (0.893) & $(0.910)$ \\
\hline \multirow[t]{2}{*}{ UCA } & $0.047^{* * *}$ & $0.048 * * *$ & $0.036^{* * *}$ & $0.050 * * *$ & $0.051^{* * *}$ & $0.050^{* * *}$ & $0.051^{* * *}$ & $0.054^{* * *}$ & $0.041^{* * *}$ & $0.039 * * *$ & $0.053^{* * *}$ & $0.038 * * *$ \\
\hline & (3.778) & (3.794) & (2.861) & (3.948) & (5.682) & (5.572) & (5.410) & (5.794) & (3.325) & (3.171) & (3.393) & (3.349) \\
\hline \multirow[t]{2}{*}{ sales/lagged K } & $0.008 * * *$ & $0.009 * * *$ & $0.011^{* * *}$ & $0.008 * * *$ & $0.011^{* * *}$ & $0.010^{* * *}$ & 0.007 & $0.011^{* * *}$ & 0.003 & 0.003 & -0.007 & 0.003 \\
\hline & $(4.070)$ & (4.225) & (4.351) & (3.768) & $(2.883)$ & (2.635) & (1.358) & (2.790) & $(0.639)$ & $(0.721)$ & $(-1.139)$ & $(0.684)$ \\
\hline \multirow[t]{2}{*}{ CF/lagged K } & $0.102 * * *$ & $0.104 * * *$ & 0.046 & $0.109 * * *$ & $0.163^{* * *}$ & $0.164 * * *$ & $0.219 * * *$ & $0.166^{* * *}$ & $0.275^{* * *}$ & $0.280 * * *$ & $0.483^{* * *}$ & $0.253^{* * *}$ \\
\hline & (3.235) & (3.269) & (1.146) & (3.359) & $(4.051)$ & (3.953) & (4.250) & (3.998) & (5.669) & (5.643) & $(4.684)$ & (5.614) \\
\hline \multirow{2}{*}{$\begin{array}{l}\text { Lagged sale } \\
\text { growth }\end{array}$} & & $0.035^{*}$ & & & & 0.003 & & & & $0.031^{* * *}$ & & \\
\hline & & $(1.960)$ & & & & $(0.371)$ & & & & $(2.845)$ & & \\
\hline \multirow[t]{2}{*}{ Avg ind Q } & & $0.360^{*}$ & & & & $0.239 * *$ & & & & 0.064 & & \\
\hline & & $(1.813)$ & & & & $(2.142)$ & & & & $(0.779)$ & & \\
\hline area dummies & yes & yes & yes & yes & yes & yes & yes & yes & yes & yes & yes & yes \\
\hline other controls & no & no & no & yes & no & no & no & yes & no & no & no & yes \\
\hline $\begin{array}{l}\text { Number of } \\
\text { observations }\end{array}$ & 2,096 & 2,046 & 2,036 & 2,033 & 3,766 & 3,683 & 3,706 & 3,676 & 1,389 & 1,364 & 1,377 & 1,359 \\
\hline Adjusted R2 & 0.070 & 0.080 & 0.062 & 0.077 & 0.080 & 0.082 & 0.074 & 0.087 & 0.064 & 0.076 & 0.051 & 0.075 \\
\hline
\end{tabular}


*** $\mathrm{p}<0.01, * * \mathrm{p}<0.05, * \mathrm{p}<0.10$. Not reported are coefficients of area dummies. The instrument in the IV columns is once-lagged (CF/lagged K). Other controls in "more control” columns include: loss of sales due to electricity, loss of sales due to transportation, road density, autonomy in investment, CEO schooling, CEO also board chairman, CEO wage/worker wage, CEO has incentive plans, the property rights protection index, 


\section{Appendix}

Table A.1. A Brief Summary of Related Studies of Financial Constrains in China

\begin{tabular}{|c|c|c|c|c|c|c|c|}
\hline & $\begin{array}{l}\text { Chan, Dang, } \\
\text { and Yan. } 2012\end{array}$ & $\begin{array}{l}\text { Chen M. } \\
2008\end{array}$ & $\begin{array}{l}\text { Chow and } \\
\text { Fung } 1998\end{array}$ & $\begin{array}{l}\text { Chow and } \\
\text { Fung, } 2000\end{array}$ & $\begin{array}{l}\text { Guariglia, } \\
\text { Liu, and } \\
\text { Song. } 2011\end{array}$ & $\begin{array}{l}\text { Héricourt } \\
\text { and Poncet. } \\
2009\end{array}$ & $\begin{array}{l}\text { Poncet, } \\
\text { Steingress and } \\
\text { Vandenbussche } \\
\text {, } 2010\end{array}$ \\
\hline Firm size & Listed firms & Listed firms & $\begin{array}{l}\text { More than } \\
80 \% \text { of the } \\
\text { firms } \\
\text { have more } \\
\text { than } 100 \\
\text { employees }\end{array}$ & $\begin{array}{l}\text { More than } \\
80 \% \text { of the } \\
\text { firms } \\
\text { have more } \\
\text { than } 100 \\
\text { employees }\end{array}$ & $\begin{array}{l}\text { sales of five } \\
\text { million yuan } \\
\text { or more: } \\
\text { SOEs } \\
\text { employ an } \\
\text { average of } \\
430 \\
\text { employees, } \\
\text { compared to } \\
250 \text { for the } \\
\text { rest of the } \\
\text { sample }\end{array}$ & $\begin{array}{l}\text { Primarily } \\
\text { small and } \\
\text { medium } \\
\text { sized }\end{array}$ & $\begin{array}{l}\text { publicly listed, } \\
\text { or minimum } \\
\text { number of } \\
\text { employees is } \\
150 \text {, or annual } \\
\text { turnover and } \\
\text { total assets are } \\
\text { at least } 10 \\
\text { million and } 20 \\
\text { million USD. }\end{array}$ \\
\hline Industries & manufacturing & $\begin{array}{l}\text { manufacturin } \\
\text { g }\end{array}$ & $\begin{array}{c}\text { manufacturin } \\
\text { g }\end{array}$ & $\begin{array}{l}\text { manufacturin } \\
\text { g }\end{array}$ & $\begin{array}{l}\text { industrial } \\
\text { firms }\end{array}$ & $\begin{array}{l}\text { manufacturi } \\
\text { ng \& } \\
\text { service }\end{array}$ & $\begin{array}{l}\text { mainly } \\
\text { manufacturing }\end{array}$ \\
\hline Locations & China & China & Shanghai & Shanghai & China & $\begin{array}{l}18 \text { Chinese } \\
\text { cities } \\
\text { in } 15 \\
\text { provinces }\end{array}$ & All China \\
\hline Time & 2005 to 2007 & 1998 to 2004 & 1989 to 1992 & 1989 to 1992 & 2000 to 2007 & $\begin{array}{l}1999 \text { to } \\
2002\end{array}$ & $\begin{array}{l}1998 \text { to } \\
2005\end{array}$ \\
\hline $\begin{array}{l}\text { Sample } \\
\text { size }\end{array}$ & 1,347 & 815 & 5,323 & 5,325 & 79,841 & 1,300 & 14,967 \\
\hline ownership & $\begin{array}{l}\text { SOEs and } \\
\text { private }\end{array}$ & $\begin{array}{l}\text { SOEs and } \\
\text { private }\end{array}$ & $\begin{array}{l}\text { All types of } \\
\text { ownership }\end{array}$ & $\begin{array}{l}\text { All types of } \\
\text { ownership }\end{array}$ & $\begin{array}{l}\text { All types of } \\
\text { ownership }\end{array}$ & $\begin{array}{l}\text { SOEs and } \\
(75 \%) \\
\text { private }\end{array}$ & $\begin{array}{l}\text { All types of } \\
\text { ownership }\end{array}$ \\
\hline $\begin{array}{l}\text { Proxy for } \\
\text { political } \\
\text { connectio } \\
\text { n }\end{array}$ & $\begin{array}{l}\text { CEO/Chairma } \\
\text { n being } \\
\text { a } \\
\text { gov’t/military } \\
\text { official or with } \\
\text { a political } \\
\text { ranking }\end{array}$ & ownership & ownership & ownership & Ownership & ownership & ownership \\
\hline findings & $\begin{array}{l}\text { Politically- } \\
\text { connected } \\
\text { firms display } \\
\text { no financing } \\
\text { constraints } \\
\text { whereas } \\
\text { firms without }\end{array}$ & $\begin{array}{l}\text { State- } \\
\text { controlled } \\
\text { firms are less } \\
\text { financially } \\
\text { constrained } \\
\text { than non- } \\
\text { state firms, }\end{array}$ & $\begin{array}{l}\text { Private } \\
\text { enterprises } \\
\text { are more } \\
\text { liquidity- } \\
\text { constrained } \\
\text { than SOEs; } \\
\text { international }\end{array}$ & $\begin{array}{l}\text { Small } \\
\text { manufacturin } \\
\text { g firms in } \\
\text { Shanghai are } \\
\text { actually less } \\
\text { liquidity- } \\
\text { constrained }\end{array}$ & $\begin{array}{l}\text { SOEs' assets } \\
\text { growth is not } \\
\text { affected by } \\
\text { liquidity } \\
\text { constraints; } \\
\text { the } \\
\text { availability }\end{array}$ & $\begin{array}{l}\text { Domestic } \\
\text { private } \\
\text { firms are } \\
\text { more credit } \\
\text { constrained } \\
\text { than SOEs. }\end{array}$ & $\begin{array}{l}\text { Private } \\
\text { Chinese firms } \\
\text { are credit } \\
\text { constrained } \\
\text { while State- } \\
\text { owned and } \\
\text { foreign-owned }\end{array}$ \\
\hline
\end{tabular}




\begin{tabular}{|c|c|c|c|c|c|}
\hline $\begin{array}{l}\text { connection } \\
\text { experience } \\
\text { significant } \\
\text { constraints. }\end{array}$ & $\begin{array}{l}\text { and firms in } \\
\text { eastern and } \\
\text { central China } \\
\text { are subject to } \\
\text { stronger } \\
\text { financial } \\
\text { constraints } \\
\text { than } \\
\text { firms in } \\
\text { western } \\
\text { China. }\end{array}$ & $\begin{array}{l}\text { joint ventures } \\
\text { are the least } \\
\text { liquidity- } \\
\text { constrained. }\end{array}$ & $\begin{array}{l}\text { than their } \\
\text { larger } \\
\text { counterparts } \\
\text { in financing } \\
\text { their fixed } \\
\text { investment. }\end{array}$ & $\begin{array}{l}\text { of internal } \\
\text { finance } \\
\text { represents a } \\
\text { binding } \\
\text { constraint } \\
\text { for the } \\
\text { growth of } \\
\text { private } \\
\text { firms. }\end{array}$ & $\begin{array}{l}\text { firms in China } \\
\text { are not }\end{array}$ \\
\hline
\end{tabular}


Table A.2. The provinces and cities of our sample

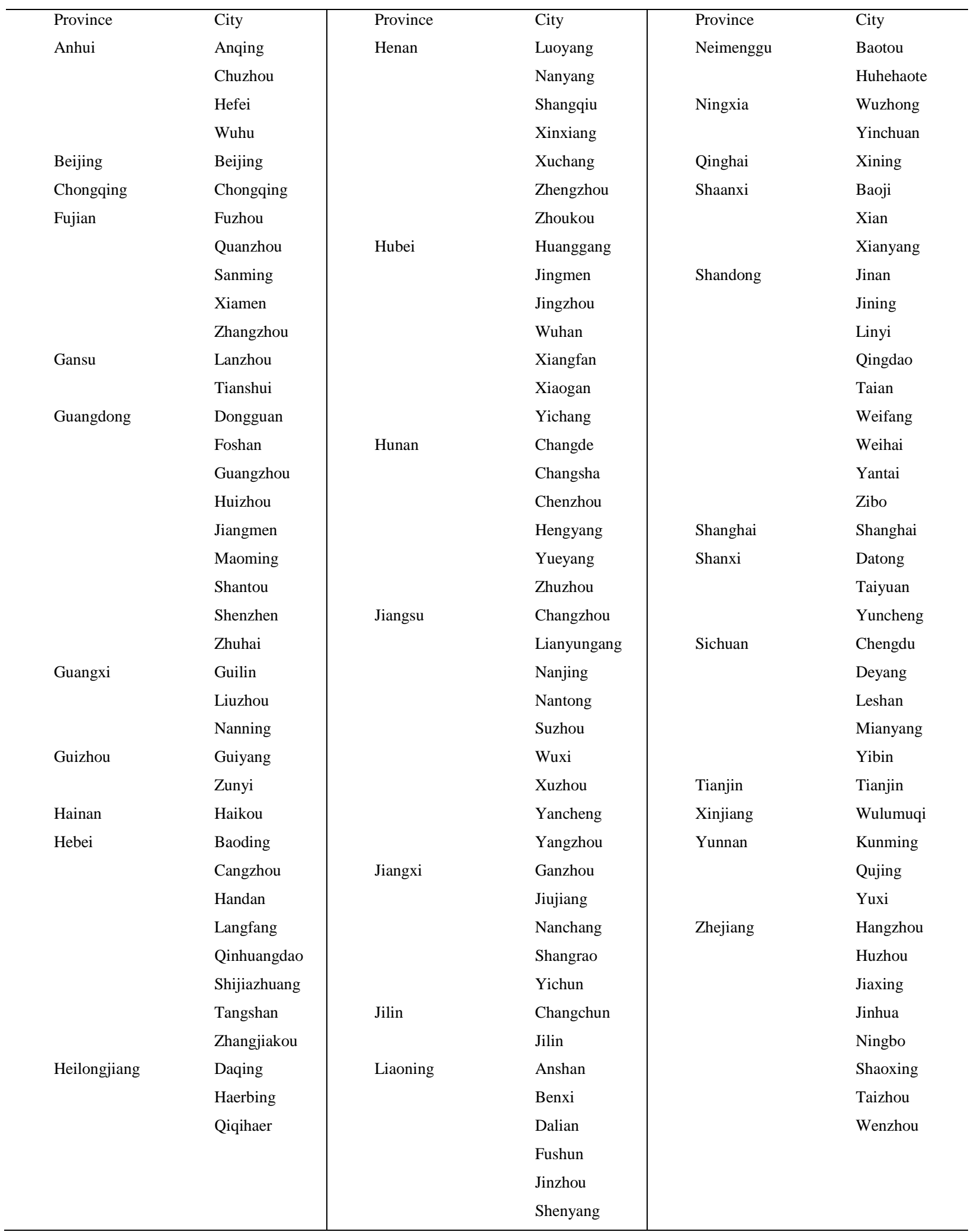


Table A.3 Industrial Distribution of Firms Surveyed in China: 2004

\begin{tabular}{|c|c|c|c|}
\hline Code & name & freq & $\%$. \\
\hline 13 & agricultural and side-line food processing & 969 & 7.81 \\
\hline 14 & food production & 243 & 1.96 \\
\hline 15 & beverages production & 178 & 1.44 \\
\hline 16 & tobacco production & 46 & 0.37 \\
\hline 17 & textiles manufacturing & 952 & 7.68 \\
\hline 18 & garment, shoes, and caps manufacturing & 206 & 1.66 \\
\hline 19 & leather, furs, down, and related products & 139 & 1.12 \\
\hline 20 & timber processing, bamboo, cane, palm fiber and straw products & 141 & 1.14 \\
\hline 21 & furniture manufacturing & 55 & 0.44 \\
\hline 22 & papermaking and paper products & 235 & 1.90 \\
\hline 23 & printing and record medium reproduction & 62 & 0.50 \\
\hline 24 & cultural, educational and sports goods & 41 & 0.33 \\
\hline 25 & petroleum processing and coking & 182 & 1.47 \\
\hline 26 & raw chemical materials and chemical products & 1441 & 11.62 \\
\hline 27 & medical and pharmaceutical products & 426 & 3.44 \\
\hline 28 & chemical fiber products & 47 & 0.38 \\
\hline 29 & rubber products & 21 & 0.17 \\
\hline 30 & plastic products & 329 & 2.65 \\
\hline 31 & nonmetal mineral products & 1299 & 10.48 \\
\hline 32 & smelting and pressing of ferrous metals & 491 & 3.96 \\
\hline 33 & smelting and pressing of non-ferrous metals & 345 & 2.78 \\
\hline 34 & metal products & 366 & 2.95 \\
\hline 35 & general machinery & 1077 & 8.69 \\
\hline 36 & equipment for special purposes & 486 & 3.92 \\
\hline 37 & transportation equipment & 989 & 7.98 \\
\hline 39 & electrical equipment and machinery & 864 & 6.97 \\
\hline 40 & electronic and telecommunications equipments & 598 & 4.82 \\
\hline 41 & instruments, meters, cultural and office machinery & 60 & 0.48 \\
\hline 42 & handicraft products and other machinery & 109 & 0.88 \\
\hline 43 & renewable materials processing & 3 & 0.02 \\
\hline Total & & 12400 & 100 \\
\hline
\end{tabular}


Table A.4. Industry-specific investment equation

\begin{tabular}{|c|c|c|c|c|c|c|c|c|}
\hline & $\begin{array}{l}\text { Ind } 1 \\
\text { coef/t }\end{array}$ & $\begin{array}{l}\text { Ind } 2 \\
\text { coef/t }\end{array}$ & $\begin{array}{l}\text { Ind } 3 \\
\text { coef } / \mathrm{t}\end{array}$ & $\begin{array}{l}\text { Ind } 4 \\
\text { coef/t }\end{array}$ & $\begin{array}{l}\text { Ind } 5 \\
\text { coef } / \mathrm{t}\end{array}$ & $\begin{array}{l}\text { Ind } 6 \\
\text { coef/t }\end{array}$ & $\begin{array}{l}\text { Ind } 7 \\
\text { coef/t }\end{array}$ & $\begin{array}{l}\text { Ind } 8 \\
\text { coef } / \mathrm{t}\end{array}$ \\
\hline ln(GDP per capita) & $\begin{array}{c}-0.139 * * * \\
(-3.146)\end{array}$ & $\begin{array}{c}0.011 \\
(0.161)\end{array}$ & $\begin{array}{c}-0.049 \\
(-1.407)\end{array}$ & $\begin{array}{c}-0.035 \\
(-0.693)\end{array}$ & $\begin{array}{c}-0.008 \\
(-0.183)\end{array}$ & $\begin{array}{c}-0.013 \\
(-0.238)\end{array}$ & $\begin{array}{c}0.035 \\
(0.609)\end{array}$ & $\begin{array}{c}-0.033 \\
(-0.673)\end{array}$ \\
\hline $\ln$ (city pop) & $\begin{array}{c}-0.001 \\
(-0.036)\end{array}$ & $\begin{array}{c}0.022 \\
(0.365)\end{array}$ & $\begin{array}{c}0.018 \\
(0.609)\end{array}$ & $\begin{array}{c}0.043 \\
(0.943)\end{array}$ & $\begin{array}{c}-0.037 \\
(-0.706)\end{array}$ & $\begin{array}{c}0.004 \\
(0.096)\end{array}$ & $\begin{array}{l}-0.091 * \\
(-1.746)\end{array}$ & $\begin{array}{c}0.070 \\
(1.553)\end{array}$ \\
\hline $\ln$ (firm age) & $\begin{array}{c}-0.071^{* * *} \\
(-2.799)\end{array}$ & $\begin{array}{c}-0.033 \\
(-0.887)\end{array}$ & $\begin{array}{l}-0.036^{*} \\
(-1.767)\end{array}$ & $\begin{array}{l}-0.061 * * \\
(-2.533)\end{array}$ & $\begin{array}{c}-0.020 \\
(-0.714)\end{array}$ & $\begin{array}{c}-0.094 * * * \\
(-3.683)\end{array}$ & $\begin{array}{c}-0.013 \\
(-0.340)\end{array}$ & $\begin{array}{l}-0.046 * \\
(-1.757)\end{array}$ \\
\hline Non-state & $\begin{array}{c}0.009 \\
(0.194)\end{array}$ & $\begin{array}{c}0.057 \\
(0.638)\end{array}$ & $\begin{array}{l}0.059^{*} \\
(1.810)\end{array}$ & $\begin{array}{c}-0.049 \\
(-0.968)\end{array}$ & $\begin{array}{l}0.086^{* *} \\
(1.994)\end{array}$ & $\begin{array}{l}0.072 * \\
(1.801)\end{array}$ & $\begin{array}{c}-0.043 \\
(-0.468)\end{array}$ & $\begin{array}{c}0.046 \\
(0.590)\end{array}$ \\
\hline Foreign & $\begin{array}{c}0.025 \\
(0.357)\end{array}$ & $\begin{array}{c}-0.085 \\
(-0.841)\end{array}$ & $\begin{array}{c}0.051 \\
(0.730)\end{array}$ & $\begin{array}{l}-0.174^{*} \\
(-1.815)\end{array}$ & $\begin{array}{c}0.069 \\
(1.042)\end{array}$ & $\begin{array}{c}-0.064 \\
(-0.863)\end{array}$ & $\begin{array}{c}-0.208^{* *} \\
(-2.159)\end{array}$ & $\begin{array}{c}-0.030 \\
(-0.344)\end{array}$ \\
\hline Loan & $\begin{array}{c}0.185^{* * *} \\
(4.406)\end{array}$ & $\begin{array}{c}0.174 * * * \\
(2.858)\end{array}$ & $\begin{array}{c}0.184^{* * *} \\
(4.525)\end{array}$ & $\begin{array}{l}0.105^{*} \\
(1.951)\end{array}$ & $\begin{array}{c}0.227^{* * *} \\
(4.216)\end{array}$ & $\begin{array}{c}0.171^{* * *} \\
(3.777)\end{array}$ & $\begin{array}{c}0.172 * * * \\
(2.729)\end{array}$ & $\begin{array}{c}0.100^{* *} \\
(2.140)\end{array}$ \\
\hline Trade credit & $\begin{array}{c}0.083 \\
(0.875)\end{array}$ & $\begin{array}{c}-0.096 \\
(-1.136)\end{array}$ & $\begin{array}{c}-0.035 \\
(-0.337)\end{array}$ & $\begin{array}{c}0.055 \\
(0.546)\end{array}$ & $\begin{array}{c}0.070 \\
(0.857)\end{array}$ & $\begin{array}{c}0.105 \\
(0.896)\end{array}$ & $\begin{array}{l}0.277^{*} \\
(1.685)\end{array}$ & $\begin{array}{c}0.146 \\
(0.742)\end{array}$ \\
\hline UCA & $\begin{array}{c}0.006 \\
(0.271)\end{array}$ & $\begin{array}{c}0.041^{* *} \\
(2.062)\end{array}$ & $\begin{array}{c}0.033^{* * *} \\
(2.828)\end{array}$ & $\begin{array}{c}0.035^{* *} \\
(1.970)\end{array}$ & $\begin{array}{c}0.050^{* * *} \\
(3.692)\end{array}$ & $\begin{array}{c}0.046^{* * *} \\
(3.857)\end{array}$ & $\begin{array}{l}0.043^{*} \\
(1.679)\end{array}$ & $\begin{array}{c}0.021 \\
(0.877)\end{array}$ \\
\hline sales/lagged K & $\begin{array}{c}0.011^{* * *} \\
(3.240)\end{array}$ & $\begin{array}{l}0.012^{*} \\
(1.750)\end{array}$ & $\begin{array}{c}0.008^{* *} \\
(1.997)\end{array}$ & $\begin{array}{l}0.012^{* *} \\
(2.091)\end{array}$ & $\begin{array}{c}0.010^{* *} \\
(2.465)\end{array}$ & $\begin{array}{c}0.009^{* *} \\
(2.062)\end{array}$ & $\begin{array}{c}0.015^{* * * *} \\
(2.889)\end{array}$ & $\begin{array}{c}0.005 \\
(0.601)\end{array}$ \\
\hline CF/lagged K & $\begin{array}{c}0.055^{* *} \\
(2.125)\end{array}$ & $\begin{array}{c}0.079 \\
(1.003)\end{array}$ & $\begin{array}{c}0.129^{* *} \\
(2.319)\end{array}$ & $\begin{array}{c}0.143^{* * *} \\
(2.740)\end{array}$ & $\begin{array}{c}0.117 * * * \\
(2.764)\end{array}$ & $\begin{array}{c}0.126 * * * \\
(2.828)\end{array}$ & $\begin{array}{c}0.093^{* *} \\
(2.061)\end{array}$ & $\begin{array}{c}0.153^{* *} \\
(1.999)\end{array}$ \\
\hline Lagged sale growth & $\begin{array}{c}0.007 \\
(0.507)\end{array}$ & $\begin{array}{c}-0.006 \\
(-0.335)\end{array}$ & $\begin{array}{c}0.016 \\
(1.074)\end{array}$ & $\begin{array}{c}0.024 \\
(1.231)\end{array}$ & $\begin{array}{c}0.034^{* *} \\
(2.321)\end{array}$ & $\begin{array}{l}0.048^{*} \\
(1.724)\end{array}$ & $\begin{array}{c}0.001 \\
(0.045)\end{array}$ & $\begin{array}{c}-0.005 \\
(-0.475)\end{array}$ \\
\hline Number of observations & 1,672 & 953 & 1,661 & 930 & 1,097 & 1,613 & 938 & 1,118 \\
\hline Adjusted R2 & 0.069 & 0.077 & 0.079 & 0.098 & 0.108 & 0.089 & 0.099 & 0.073 \\
\hline
\end{tabular}

Note. $^{* * *} \mathrm{p}<0.01,{ }^{* *} \mathrm{p}<0.05,{ }^{*} \mathrm{p}<0.10 . \quad$ The coefficients for area dummies are not reported..

Industry 1 includes agricultural processing, wood processing, furniture, paper, food, drink, tobacco, educational and sports goods, craft, and printing. Industry 2 includes textile, cloth shoe and hat, and leather. Industry 3 includes petroleum, chemical fiber, chemical material, rubber, and plastic. Industry 4 represents general equipment. Industry 5 includes communication equipment and electronics. Industry 6 includes specialized equipment, instruments, medical equipment, and transportation equipment. Industry 7 includes metal, non-ferrous metals, and ferrous metals. Industry 8 includes non-metal manufacturing. 
Table A.5. Variable definitions

\begin{tabular}{|c|c|}
\hline & Definitions \\
\hline I/lagged K & $\begin{array}{l}\text { The ratio of investment over lagged capital stock. Capital stock is } \\
\text { measured as the net value of fixed assets. }\end{array}$ \\
\hline Ln(GDP per capita) & Log GDP per capita of the city in which the firm is located. \\
\hline Ln(city population) & Log population in the city in which the firm is located. \\
\hline Firm age & Firm age in number of years. \\
\hline Non-state & $\begin{array}{l}\text { A dummy variable that is one when the ownership is corporation, } \\
\text { collective, private. }\end{array}$ \\
\hline Foreign & $\begin{array}{l}\text { A dummy variable that is one when the ownership is foreign or } \\
\text { "Hong Kong, Macao and Taiwan". }\end{array}$ \\
\hline Loan & A dummy variable for having access to bank loans. \\
\hline Trade credit & $\begin{array}{l}\text { Access to trade credit, as measured by the share of input purchased } \\
\text { through trade credit. }\end{array}$ \\
\hline UCA & $\begin{array}{l}\text { The ratio of unpledged collateralizable assets (i.e., the value of } \\
\text { fixed assets minus total loans) to lagged capital stock. }\end{array}$ \\
\hline Sales/lagged K & The ratio of sales to lagged capital stock. \\
\hline CF/lagged K & $\begin{array}{l}\text { Cash flow (i.e., the summation of net income, interest payments, } \\
\text { financing charges, and tax payable) over lagged capital stock. }\end{array}$ \\
\hline Lagged sales growth & Sales growth from the previous year, lagged by one year. \\
\hline Tobin’s Q & $\begin{array}{l}\text { Industry-level average Tobin's Q. A firm's Q value is market value } \\
\text { of a firm’s total assets over the book value of those assets. We } \\
\text { rely on data from all listed firms in China to obtain industry- } \\
\text { level average Tobin's Q using the value-weighted formula. }\end{array}$ \\
\hline Industry Q & Same as above, but use industry-year average. \\
\hline CEO schooling & CEO schooling in number of years. \\
\hline CEO appointed by gov’t & $\begin{array}{l}\text { A dummy variable indicating that the CEO was appointed by the } \\
\text { government. }\end{array}$ \\
\hline CEO also board chairman & $\begin{array}{l}\text { A dummy variable that the CEO was also chair of the board of } \\
\text { directors. }\end{array}$ \\
\hline CEO wage/worker wage & The ratio of CEO wage over average worker wage. \\
\hline PR protection & $\begin{array}{l}\text { An index of the firm's evaluation of the degree of property rights } \\
\text { protection. }\end{array}$ \\
\hline ETC & $\begin{array}{l}\text { The ratio of entertainment and travelling costs over sales, a proxy of } \\
\text { corruption (Cai, Fang and Xu 2004). }\end{array}$ \\
\hline $\begin{array}{l}\text { CEO income linked to operating } \\
\text { performance }\end{array}$ & $\begin{array}{l}\text { A dummy variable that is one when CEO earning is linked to the } \\
\text { firm’s operating performance. }\end{array}$ \\
\hline $\begin{array}{l}\text { \% CEO income increase if } \\
\text { surpassing performance } \\
\text { threshold }\end{array}$ & $\begin{array}{l}\text { The percentage increase in CEO income if the firm's performance } \\
\text { surpasses an ex ante specified performance target. Based on the } \\
\text { survey questionnaire on CEO incentives. }\end{array}$ \\
\hline
\end{tabular}

